University of Nebraska - Lincoln

DigitalCommons@University of Nebraska - Lincoln

\title{
Soils of temperate rainforests of the North American Pacific Coast
}

Dunbar N. Carpenter

University of Wisconsin-Madison, dncarpenter@wisc.edu

James G. Bockheim

University of Wisconsin-Madison,, bockheim@wisc.edu

Paul F. Reich

USDA Natural Resources Conservation Service, Beltsville, MD, paul.reich@wdc.usda.gov

Follow this and additional works at: https://digitalcommons.unl.edu/usdaarsfacpub

Part of the Forest Biology Commons, and the Other Ecology and Evolutionary Biology Commons

Carpenter, Dunbar N.; Bockheim, James G.; and Reich, Paul F., "Soils of temperate rainforests of the North American Pacific Coast" (2014). Publications from USDA-ARS / UNL Faculty. 1413.

https://digitalcommons.unl.edu/usdaarsfacpub/1413

This Article is brought to you for free and open access by the U.S. Department of Agriculture: Agricultural Research Service, Lincoln, Nebraska at DigitalCommons@University of Nebraska - Lincoln. It has been accepted for inclusion in Publications from USDA-ARS / UNL Faculty by an authorized administrator of DigitalCommons@University of Nebraska - Lincoln. 


\title{
Soils of temperate rainforests of the North American Pacific Coast
}

\author{
Dunbar N. Carpenter ${ }^{\text {a }}$, James G. Bockheim ${ }^{\mathrm{b}, *}$, Paul F. Reich ${ }^{\mathrm{c}}$ \\ a Department of Forest and Wildlife Ecology, University of Wisconsin-Madison, 1630 Linden Drive, Madison, WI 53706-1299, USA \\ b Department of Soil Science, University of Wisconsin-Madison, 1525 Observatory Drive, Madison, WI 53706-1299, USA \\ c World Soil Resources, USDA Natural Resources Conservation Service, 5601 Sunnyside Ave, Beltsville, MD 20705-5471, USA
}

\section{A R T I C L E I N F O}

\section{Article history:}

Received 8 November 2013

Received in revised form 7 April 2014

Accepted 16 April 2014

Available online $\mathrm{xxxx}$

\section{Keywords:}

Soil classification

Environmental gradients

Soil properties

Temperate environment

Rainforests

Forest soils

\begin{abstract}
A B S T R A C T
Temperate rainforests have high conservation and natural resource value, but the soils of this bioregion have not previously been studied as a unit. Here we examine the soils of North America's Pacific coastal temperate rainforests, utilizing databases from the United States Natural Resources Conservation Service and the Canadian Centre for Land and Biological Resources Research to (i) identify the soil taxa, (ii) evaluate the soil properties, and (iii) compare soils in temperate and tropical rainforests. There are strong climate gradients within these temperate rainforests, with the mean temperature declining from $11.7^{\circ} \mathrm{C}$ to $6.1^{\circ} \mathrm{C}$ and the mean annual precipitation increasing from $1500 \mathrm{~mm}$ to around $3000 \mathrm{~mm}$ from northern California (CA) to northwestern British Columbia (BC) and southeastern Alaska (AK). There is also high pedodiversity in this region, with soils representing 8 orders and 31 suborders, and, in the US portion, 65 great-groups, 142 subgroups, and 482 soil series. Twenty-six percent of described soil series are endemic to temperate rainforests in the US portion of the region, with the proportion declining with latitude. Dominant soil suborders vary along the latitudinal gradient from Humults-Udalfs/ Ustalfs-Udepts-Udults in CA, to Udands-Udepts-Udands Humults in western Oregon (OR) and Washington (WA), to Orthods-Folists in BC and Cryods-Saprists in AK. The dominant diagnostic horizons are ochric/argillic (CA), umbric/cambic (OR, WA), and albic-histic/spodic (BC, AK). Whereas soils in CA, BC, and AK tend to have a mixed mineralogy, those in northern OR and WA commonly are derived from volcaniclastic materials and have a ferrihydritic or isotic mineralogy. Soils in this region are generally deep, hold abundant moisture, are not subject to deep-freezing, and are enriched in extractable Fe and Al. Organic C and total N contents are high overall, but also variable, with right-skewed distributions. Compared to tropical rainforest soils in the Pacific Basin, Pacific temperate rainforest have greater weatherable minerals, cation-exchange capacities, soil organic C, and total exchangeable base cations. However, soils of both bioregions tend to be deep, acidic Al-saturated, and can have large $\mathrm{N}$ reservoirs. This investigation provides a foundation for a more unified understanding of the soils of a globally significant bioregion.
\end{abstract}

@ 2014 Elsevier B.V. All rights reserved.

\section{Introduction}

Temperate rainforests have not received the same attention as their tropical counterparts, and though they make up only about $2 \%$ of the world's forests, they hold high value for both conservation and natural resources (DellaSala et al., 2011). These forests, sometimes called wet temperate forests, have been defined in several ways. Alaback (1991) laid out four parameters, later refined by Kellogg (1992): (i) greater than $1400 \mathrm{~mm}$ of annual precipitation, with at least $10 \%$ occurring during the summer; (ii) cool, frequently overcast summers, with a July (or austral January) isotherm of $<16{ }^{\circ} \mathrm{C}$; (iii) infrequent fires; and (iv) a dormant season caused by low temperatures, potentially accompanied by transient snow. For conservation purposes, DellaSala et al. (2011) built upon this definition and constructed a rainforest climate

\footnotetext{
* Corresponding author. Tel.: +1 608263 5903; fax: +1 6082652595.

E-mail addresses: dncarpenter@wisc.edu (D.N. Carpenter), bockheim@wisc.edu (J.G. Bockheim), paul.reich@wdc.usda.gov (P.F. Reich).
}

model that acknowledged rainforests in boreal regions and highlighted several outlier regions of previously less-recognized rainforests. Worldwide, temperate rainforests occupy over $400,000 \mathrm{~km}^{2}$, and well over 1 million $\mathrm{km}^{2}$ by some estimates and definitions (Table 1 ). The largest areas occur in northwestern North America and southwestern South America, with substantial areas also found in East Asia, Australasia, and western Eurasia.

Temperate rainforests, like their tropical counterparts, are highly productive and also contain some of the highest densities of biomass of any terrestrial ecosystem (Keith et al., 2009; Waring and Franklin, 1979). Soils in tropical rainforests are commonly Oxisols and Ultisols, which generally have low levels of nutrients and weatherable minerals (Coscione et al., 2005; Padmanabhan et al., 2012). To mitigate against the poor soil conditions, tropical rainforests have adapted special mechanisms to cycle nutrients more directly from the plant to the rooting zone (Stark and Jordan, 1978). Soils of temperate rainforests have not been studied as comprehensively as those of tropical rainforests. Maintaining the productivity of temperate rainforests to meet increasing 
Table 1

Global distribution of temperate rainforests.

Area estimates are compiled from Kellogg (1992) and DellaSala et al. (2011).

\begin{tabular}{lll}
\hline Region & Location(s) & $\begin{array}{l}\text { Area estimates } \\
{\left[\mathrm{km}^{2}\right]}\end{array}$ \\
\hline $\begin{array}{l}\text { Northwestern } \\
\text { North America }\end{array}$ & All & $\begin{array}{l}207,000-320,000 \\
207,000-273,000\end{array}$ \\
& Inland Northwest & $0-72,000$ \\
South America & Chile, southwestern Argentina & $120,000-126,000$ \\
Australasia & Tasmania, New Zealand, eastern Australia & $46,000-86,000$ \\
East Asia & Japan, Korea, eastern Russian & $24,000-151,000$ \\
Western Eurasia & Caucasus, Alps, British Isles (relicts) & $39,000-180,000$ \\
Others & Eastern North America, South Africa, & $0-100,000+$ \\
Total & Himalayas & $436,000-$ \\
This study & & $1,308,000+$ \\
& North American Pacific Coast, excluding & 166,331
\end{tabular}

human demands requires a complete understanding of these ecosystems, including their soils (Kimmins, 1996). Based on a few studies, these soils appear to be moderately weathered (Bockheim et al., 1996; Burt and Alexander, 1996; Hedin et al., 1995; Heilman and Gass, 1974) and enriched in soil organic carbon and nitrogen (Edmonds and Chappell, 1994; Huygens et al., 2008; Perakis and Sinkhorn, 2011; Smithwick et al., 2002). Most temperate rainforests occur near oceans that help maintain a mild climate conducive to a long growing season, evergreen vegetation, and slow rates of decomposition (Lawford et al., 1995; Waring and Franklin, 1979). Abundant precipitation can lead to rapid leaching (Burt and Alexander, 1996; Langley-Turnbaugh and Bockheim, 1998; Ugolini, 1968). Marine inputs appear to be important in the nutrition of these ecosystems and their soils (Bockheim and Langley-Turnbaugh, 1997; Gende et al., 2002). Diverse topography and histories of glaciation and volcanism in many temperate rainforest regions contribute to a variety of parent materials and weathering processes (Alexander and Burt, 1996; Bockheim et al., 1996; Briggs et al., 2006).

Given this particular combination of pedogenic factors, what sorts of soils are found in temperate rainforests, and how does this help us understand the ecosystems in this bioregion? To our knowledge, no one has yet investigated the characteristics of temperate rainforest soils as a unit. The objectives of this study are to delineate the soils in North America's Pacific coastal temperate rainforests, evaluate their properties, and discuss their role in rainforest ecosystems in comparison with their tropical counterparts. We utilize data from the US and Canadian soil databases and draw from a wide range of published literature to synthesize our knowledge of temperate rainforest soils of North America's Pacific Coast.

\section{Coastal temperate rainforests of the North American Pacific Coast}

\subsection{Study area}

We focus on the soils of the rainforests of North America's Pacific Coast (NAPC). This region, sometimes referred to as the Pacific Northwest, spans much of the west coast of the US and Canada, up to about $85 \mathrm{~km}$ inland. Though rainforests exist further inland (e.g. in the western Cascade mountains), there is less consensus over their delineation (DellaSala et al., 2011), and we decided to limit our study to the most quintessential rainforests on the coast. The study region consists of the Coast Range and Coastal Western Hemlock-Sitka Spruce Forest ecoregions (Level III), as defined by the North American Commission on Environmental Cooperation (Wiken et al., 2011; Fig. 1). Within the study region, soils have been divided into ecological units - Major Land Resource Areas (MLRAs; Natural Resource Conservation Service, 2006) in the US and Ecoregions in Canada (Demarchi, 2011; Ecological Stratification Working Group, 1996; Fig. 1). The US subregions include

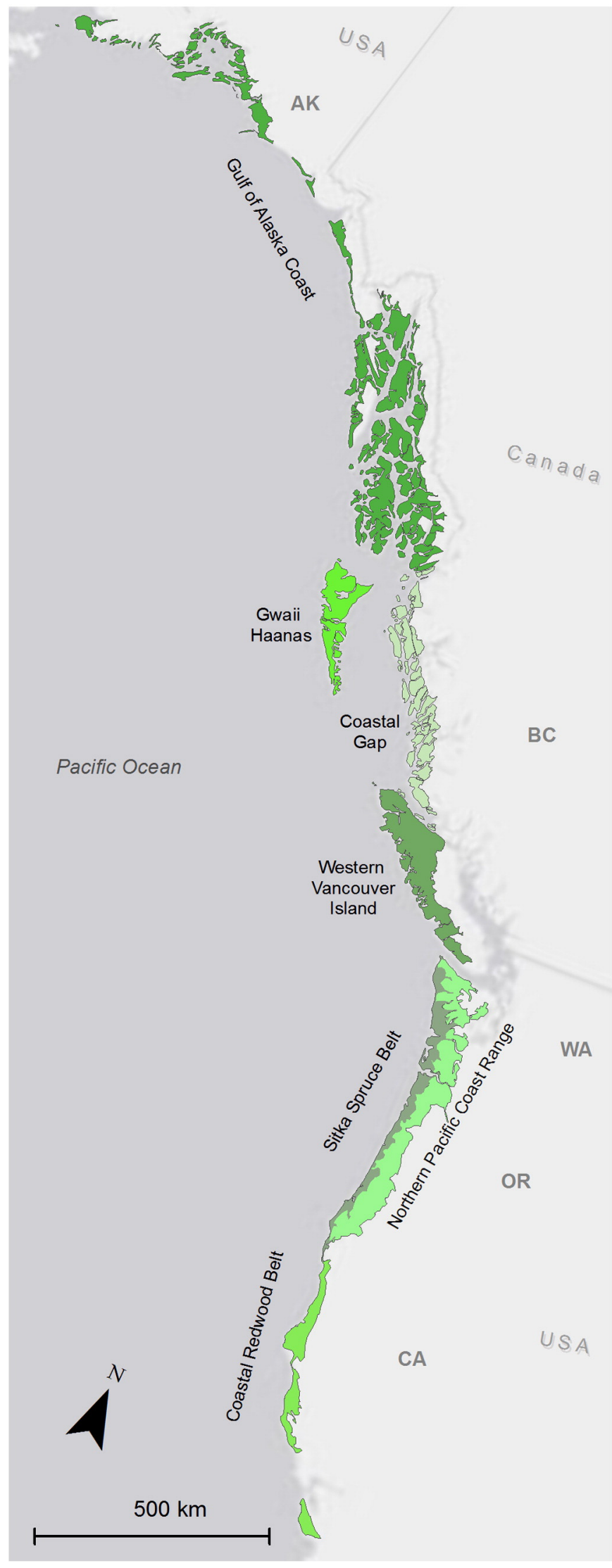

Fig. 1. The coastal temperate rainforests of western North America and subregions. 
the Northern Coast Range and Sitka Spruce Belt (MLRA 1 and 4A) in western Oregon (OR) and Washington (WA), the Coastal Redwood Belt (MLRA 4B) in northern California (CA), and the Gulf of Alaska Coast (MLRA 220) in southeastern Alaska (AK). The Canadian subregions are all in the coastal British Columbia (BC), and include Western Vancouver Island (Ecoregion 193), Gwaii Haanas (Ecoregions 188 and 189; formerly Queen Charlotte Ranges and Lowlands), and the portion of the Coastal Gap (Ecoregion 191) falling inside the larger study region boundaries.

\subsection{Climate}

The climate of NAPC rainforests has been described in detail elsewhere (e.g. Lawford et al., 1995), but can be generally characterized as mild-temperate mesothermal (Köppen Group C), with warm summers that range from dry in the south (Köppen Csb) to humid in the north (Köppen $\mathrm{Cfb}$ ). Annual precipitation ranges from an average of $1500 \mathrm{~mm}$ in the Coastal Redwood Belt to $3300 \mathrm{~mm}$ in the Coastal Gap ecoregion (Table 2). Snow becomes more frequent with increasing latitude, accounting for less than $10 \%$ of precipitation in the south, but over $50 \%$ in the north. Mean annual air temperature decreases with latitude from $11.7^{\circ} \mathrm{C}$ in the Coastal Redwood Belt to $6.1{ }^{\circ} \mathrm{C}$ along the Gulf of Alaska Coast (Table 2).

\subsection{Vegetation}

Vegetation in NAPC rainforests is dominated by about a dozen species of long-lived conifers, along with a few deciduous hardwoods, some less-common conifers, and a great diversity of understory plants. Most trees in the region have potential lifespans of over 400 years, with some able to live well over 1000 years (Waring and Franklin, 1979). Aboveground biomass in temperate rainforests of the NAPC ranges from 300 to $1000 \mathrm{Mg} / \mathrm{ha}$, productivity from 5 to $>15 \mathrm{Mg} / \mathrm{ha} / \mathrm{yr}$, and tree species richness from 2 to 20 (DellaSala et al., 2011; Hudiburg et al., 2009; Waring and Franklin, 1979). Disturbances include localized windthrow, landslides, and flooding; large, stand-replacing disturbances (e.g. fire) are uncommon, allowing succession to old-growth stages dominated by gap-phase dynamics.

Trees in the Coastal Redwood Belt include coastal redwood (Sequoia sempervirons), Douglas-fir (Pseudotsuga menziesii), grand fir (Abies grandis), bishop pine (Pinus muricata), western red cedar (Thuja plicata), Sitka spruce (Picea sitchensis), Port Orford cedar (Chamaecyparis lawsoniana), red alder (Alnus rubra), California bay laurel (Umbellularia californica), golden chinkapin (Castanoptis chrysophylla), Pacific madrone (Arbutus menziesii), tanoak (Notholithocarpus densiflorus), and California black oak (Quercus kelloggii). Important understory species are red huckleberry (Vaccinium parvifolium), California huckleberry (Vaccinium ovatum), western swordfern (Polystichum munitum), wood-sorel (Oxalis spp.), Trillium spp., and Rhododendron spp. The Sitka Spruce Belt and Northern Pacific Coast Range forests contain Sitka spruce, western hemlock (Tsuga heterophylla), western red cedar, red alder, and Douglas-fir, along with lesser amounts of grand fir (A. grandis), bigleaf maple (Acer macrophyllum), and, at higher elevations, noble fir (Abies procera). The understory contains salal (Gaultheria shallon), swordfern, red huckleberry, wood sorel, Rhododendron spp., Oregon-grape (Mahonia aquifolium), Rubus spp., violets (Viola spp.), and Trillium spp. Forests in coastal BC (Western Vancouver Island, Gwaii Haanas, and Coastal Gap ecoregions) and the Gulf of Alaska Coast contain western hemlock, Sitka spruce, western red cedar, alder (Alnus spp.), Pacific Silver fir (Abies amabalis), shore pine (Pinus contorta subsp. contorta), mountain hemlock (Tsuga mertensiana), and Alaska yellow-cedar (Chamaecyparis nootkatensis). Common understory plants include step moss (Hylocomium splendens), salal, deer fern (Blechnum spicant), and Alaskan blueberry (Vaccinium alaskaense).

\subsection{Physiography and soils}

The physiography of the region is dominated by the Pacific Coast Ranges. In addition to isolated headlands, the landforms include uplifted marine terraces, sand dunes, river valleys cut through the mountains, and from northwest WA northward, glaciated terrain and colluvial fans. The soil parent materials include residuum, colluvium, marine deposits, alluvium, till, and volcanic ash. The latter deposits are most common in WA and southeast AK but occur throughout the area. Slopes commonly range between 0 and $90 \%$ and elevations from 0 to $2200 \mathrm{~m}$ above sea level (Natural Resource Conservation Service, 2006). The Natural Resource Conservation Service (2006) and Jungen and Lewis (1978) provide further discussion of physiography in the region.

According to the general soil maps of the USA (Soil Survey Staff, 2013a) and Canada (Centre for Land and Biological Resources Research, 1996), the dominant soil orders (suborders) in the western North America temperate rainforest are Alfisols (Ustalfs, Udalfs), Inceptisols (Udepts), and Ultisols (Udults) in northern CA, Inceptisols (Udepts) and Spodosols (Orthods) in OR, Andisols (Udands) in WA, Spodosols (Cryods/Ferro-Humic Podzols) and Histosols (Folists/ Folisols) in BC, and Spodosols (Cryods) and Histosols (Saprists) in southeastern AK.

\section{Methods}

In the US portion of the study region, we identified dominant soil series within each subregion (MLRA) using the Natural Resource Conservation Service soil classification database (Soil Survey Staff, 2013b). A 50\% cutoff was used to consider a soil series "dominant" in given county. Soil taxonomic features (to family level), site factors (e.g. climate, parent materials), general soil characteristics (e.g. soil depth, drainage class, temperature and moisture regime), and diagnostic horizons were determined from Official Soil Series Descriptions (Soil Survey Staff, 2013c). The Soil Survey Geographic (SSURGO) Database (Soil Survey Staff, 2012) was used to generate soil maps for each MLRA. Extraction of soil map data was accomplished using a vector database of MLRAs (Natural Resource Conservation Service, 2006). Each SSURGO map unit is made up of component soils. The component with the highest percent coverage was selected as the dominant component for soil map preparation.

Soil property characterization data were obtained from Soil Laboratory Data (National Cooperative Soil Survey, 2013) for available and randomly selected soil series for major soil taxa. We used the laboratory data to calculate profile average $\mathrm{pH}$, cation exchange capacity (CEC), $\mathrm{Al}$ saturation and base saturation, as well as profile (to $100 \mathrm{~cm}$ ) quantities of soil organic C, total $\mathrm{N}$, exchangeable bases ( $\mathrm{Ca}, \mathrm{Mg}$, $\mathrm{Na}$, and $\mathrm{K}$ ), and $\mathrm{C}: \mathrm{N}$ ratio, based on bulk density and stone content. Missing bulk density values were estimated using the pedotransfer functions of Heuscher et al. (2005) where feasible ( $31 \%$ of horizons), and additional missing data (bulk density ( $~ 8 \%$ of horizons), coarse fragments ( $38 \%$ of horizons), and total N ( $14 \%$ of horizons)) were estimated from comparable pedons and horizons where reasonable (see Supplement S1). We calculated summary statistics for analytic properties across all soil profiles and compare them with other local and global sources. A number of the properties examined have right-skewed distributions, so in addition to reporting mean (MN), minimum, and maximum values, we also report median (MD) and interquartile range (IQR; i.e. 25th-75th percentiles), which are more robust to outliers and skewed distributions.

The $\mathrm{BC}$ portion of the study region is largely outside the agricultural zone of Canada where detailed soil property and taxonomic data are available. Extensive soil spatial data exists only at a relatively coarse scale of 1:1 million. To identify and map BC soil taxa and characteristics, we used the Soil Landscapes of Canada database (Centre for Land and Biological Resources Research, 1996), Soil Landscapes of BC descriptions (Jungen and Lewis, 1978) and the Canadian guide to soil classification (Soil Classification Working Group, 1998). Mapping in BC was similarly 
Table 2

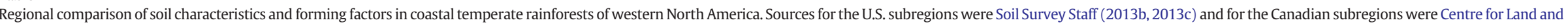
Biological Resources Research (1996), Jungen and Lewis (1978) and Soil Classification Working Group (1998).

\begin{tabular}{|c|c|c|c|c|c|c|c|}
\hline Subregion & $\begin{array}{l}\text { Coastal Redwood } \\
\text { Belt } \\
\text { (MLRA 4B) }\end{array}$ & $\begin{array}{l}\text { Sitka Spruce Belt } \\
\text { (MLRA 4A) }\end{array}$ & $\begin{array}{l}\text { Northern Pacific Coast } \\
\text { Range } \\
\text { (MLRA 1) }\end{array}$ & $\begin{array}{l}\text { Western Vancouver Island } \\
\text { (Ecoregion 193) }\end{array}$ & $\begin{array}{l}\text { Coastal Gap } \\
\text { (Ecoregion 191) }\end{array}$ & $\begin{array}{l}\text { Gwaii Haanas } \\
\text { (Ecoregions } 188 \text { \& 189) }\end{array}$ & $\begin{array}{l}\text { Gulf of Alaska Coast } \\
\text { (MLRA 220) }\end{array}$ \\
\hline $\begin{array}{l}\text { Total area (area of mapped } \\
\text { soil series) }\left[\mathrm{km}^{2}\right]\end{array}$ & $12,095(4550)$ & $13,740(10,440)$ & $26,675(23,481)$ & 20,088 (na) & $15,455(\mathrm{na})$ & $10,193(n a)$ & $71,085(17,732)$ \\
\hline Mean annual air temperature $\left[{ }^{\circ} \mathrm{C}\right]$ & 11.7 & 9.4 & 8.9 & 8.5 & 7.5 & 8.0 & 6.1 \\
\hline Mean annual precipitation [mm] & 1500 & 2500 & 2300 & 3000 & 3300 & 1800 & 2600 \\
\hline No. of soil series & 63 & 173 & 214 & nd & nd & nd & 32 \\
\hline Ranking soil orders & $\begin{array}{l}\text { Ultisols (41\%), } \\
\text { Alfisols (21\%), } \\
\text { Inceptisols (19\%) }\end{array}$ & $\begin{array}{l}\text { Andisols (49\%), } \\
\text { Inceptisols (30\%), } \\
\text { Ultisols (9\%) }\end{array}$ & $\begin{array}{l}\text { Inceptisols (43\%), } \\
\text { Andisols (31\%), } \\
\text { Ultisols (15\%) }\end{array}$ & $\begin{array}{l}\text { Podzolic/Spodosols } \\
(85 \%)\end{array}$ & $\begin{array}{l}\text { Podzolic/Spodosols (50\%), } \\
\text { Organic/Histosols (48\%) }\end{array}$ & $\begin{array}{l}\text { Podzolic/Spodosols (83\%), } \\
\text { Organic/Histosols (16\%) }\end{array}$ & $\begin{array}{l}\text { Spodosols (56\%), } \\
\text { Histosols (19\%) }\end{array}$ \\
\hline Dominant parent materials & $\begin{array}{l}\text { Residuum \& } \\
\text { colluvium (75\%) }\end{array}$ & $\begin{array}{l}\text { Colluvium (29\%), } \\
\text { alluvium (23\%), } \\
\text { residuum (16\%) }\end{array}$ & $\begin{array}{l}\text { Colluvium \& } \\
\text { residuum (49\%), } \\
\text { colluvium (20\%), } \\
\text { alluvium (14\%) }\end{array}$ & $\begin{array}{l}\text { Colluvium (62\%), } \\
\text { till (18\%) }\end{array}$ & $\begin{array}{l}\text { Colluvium (44\%), } \\
\text { organic (40\%) }\end{array}$ & $\begin{array}{l}\text { Till (57\%), } \\
\text { colluvium (27\%) }\end{array}$ & $\begin{array}{l}\text { Colluvium, } \\
\text { residuum (50\%), } \\
\text { organic (19\%) }\end{array}$ \\
\hline Depth & Deep & Deep & Deep & Shallow to moderately deep & Shallow to moderately deep & Shallow to moderately deep & $\begin{array}{l}\text { Shallow to moderately } \\
\text { deep }\end{array}$ \\
\hline Drainage class & Moderately well to well & Moderately well & Moderately well to well & Moderately well to well & Well & Moderately well to well & Moderately well \\
\hline Mineral class & Mixed (90\%) & $\begin{array}{l}\text { Ferrihydritic (41\%), } \\
\text { isotic (34\%), } \\
\text { mixed (23\%) }\end{array}$ & $\begin{array}{l}\text { Isotic ( } 45 \%) \text {, } \\
\text { ferrihydritic (28\%), } \\
\text { mixed (21\%) }\end{array}$ & Mixed & Mixed & Mixed & mixed (100\%) \\
\hline Soil-temperature regime & Isomesic & $\begin{array}{l}\text { Isomesic (80\%), } \\
\text { isofrigid (19\%) }\end{array}$ & $\begin{array}{l}\text { Mesic ( } 70 \%) \text {, } \\
\text { cryic or frigid (30\%) }\end{array}$ & $\begin{array}{l}\text { Isomesic, } \\
\text { isofrigid, } \\
\text { cryic }\end{array}$ & $\begin{array}{l}\text { Isomesic, } \\
\text { isofrigid, } \\
\text { cryic }\end{array}$ & $\begin{array}{l}\text { Isomesic, } \\
\text { isofrigid, } \\
\text { cryic }\end{array}$ & Cryic \\
\hline Soil-moisture regime & $\begin{array}{l}\text { Udic (65\%), } \\
\text { ustic (17\%) }\end{array}$ & $\begin{array}{l}\text { Udic (84\%), } \\
\text { aquic (16\%) }\end{array}$ & Udic (89\%) & $\begin{array}{l}\text { Udic, } \\
\text { aquic }\end{array}$ & $\begin{array}{l}\text { Udic, } \\
\text { aquic }\end{array}$ & $\begin{array}{l}\text { Udic, } \\
\text { aquic }\end{array}$ & $\begin{array}{l}\text { Udic (66\%), } \\
\text { aquic (34\%) }\end{array}$ \\
\hline Particle-size class & $\begin{array}{l}\text { Fine-loamy (41\%), } \\
\text { fine (25\%), } \\
\text { loamy-skeletal (16\%) }\end{array}$ & $\begin{array}{l}\text { Medial or medial- } \\
\text { skeletal (48\%), } \\
\text { fine (16\%), } \\
\text { fine-loamy (10\%) }\end{array}$ & $\begin{array}{l}\text { Medial or medial- } \\
\text { skeletal (30\%), } \\
\text { loamy-skeletal (21\%), } \\
\text { fine }(17 \%)\end{array}$ & $\begin{array}{l}\text { Loamy-skeletal, } \\
\text { sandy-skeletal }\end{array}$ & $\begin{array}{l}\text { Loamy-skeletal, } \\
\text { sandy-skeletal, } \\
\text { organic }\end{array}$ & $\begin{array}{l}\text { Loamy-skeletal, } \\
\text { sandy-skeletal }\end{array}$ & $\begin{array}{l}\text { Loamy-skeletal (53\%), } \\
\text { organic }(19 \%)\end{array}$ \\
\hline Cation-exchange activity class & $\begin{array}{l}\text { Superactive ( } 43 \%) \text {, } \\
\text { semi-active (19\%), } \\
\text { active (22\%) }\end{array}$ & $\begin{array}{l}\text { None (89\%), } \\
\text { superactive (9\%) }\end{array}$ & $\begin{array}{l}\text { None }(82 \%) \text {, } \\
\text { superactive }(10 \%)\end{array}$ & $\begin{array}{l}\text { None, } \\
\text { superactive }\end{array}$ & $\begin{array}{l}\text { None, } \\
\text { superactive }\end{array}$ & $\begin{array}{l}\text { None, } \\
\text { superactive }\end{array}$ & Superactive (66\%) \\
\hline Dominant diagnostic epipedon & Ochric (73\%) & $\begin{array}{l}\text { Umbric ( } 60 \%), \\
\text { ochric (27\%) }\end{array}$ & $\begin{array}{l}\text { Ochric (52\%), } \\
\text { umbric ( } 42 \%)\end{array}$ & None & Organic & Organic & $\begin{array}{l}\text { Histic (34\%), } \\
\text { albic (47\%) }\end{array}$ \\
\hline Epipedon thickness [cm] & 33 & 38 & 30 & - & Usually $\geq 40$ & Usually $\geq 40$ & 20 \\
\hline $\begin{array}{l}\text { Dominant diagnostic subsurface } \\
\text { horizon }\end{array}$ & Argillic (71\%) & $\begin{array}{l}\text { Cambic ( } 74 \%) \text {, } \\
\text { none (10\%) }\end{array}$ & $\begin{array}{l}\text { Cambic (76\%), } \\
\text { argillic (22\%) }\end{array}$ & Podzolic & Podzolic & Podzolic & Spodic (56\%) \\
\hline Subsurface diagn. hor. thickness $[\mathrm{cm}]$ & 91 & 69 & 71 & $\geq 10$ & $\geq 10$ & $\geq 10$ & 23 \\
\hline
\end{tabular}


Table 3a

Soil taxa in coastal temperate rainforests of the western United States. Number of soil series in each subgroup indicated in parentheses.

Data from Soil Survey Staff (2013b, 2013c).

\begin{tabular}{|c|c|c|c|c|}
\hline Order & Suborder & Great group & Subgroup & Area $\left[\mathrm{km}^{2}\right]$ \\
\hline \multirow[t]{8}{*}{ Alfisols } & \multirow[t]{2}{*}{ Aqualfs } & Endoaqualfs & Umbric (1) & 17 \\
\hline & & Glossaqualfs & Typic (1) & 195 \\
\hline & \multirow[t]{2}{*}{ Udalfs } & Glossudalfs & Oxyaquic (3), Oxyaquic Vertic (2) & 77 \\
\hline & & Hapludalfs & Aquultic (1), Mollic (2), Oxyaquic (1), Ultic (8) & 928 \\
\hline & Ustalfs & Haplustalfs & Ultic (4) & 1326 \\
\hline & \multirow[t]{2}{*}{ Xeralfs } & Haploxeralfs & Aquultic (1) & 7 \\
\hline & & Palexeralfs & Aquic (1), Ultic (1) & 521 \\
\hline & \multicolumn{2}{|l|}{ Subtotal } & & 3071 \\
\hline \multirow[t]{11}{*}{ Andisols } & \multirow[t]{4}{*}{ Aquands } & Duraquands & Typic (1) & 17 \\
\hline & & Endoaquands & Alic (1) & 5 \\
\hline & & Epiaquands & Alic (3) & 31 \\
\hline & & Melanaquands & Typic (4) & 3 \\
\hline & \multirow[t]{2}{*}{ Cryands } & Fulvicryands & Pachic (1), Typic (3) & 48 \\
\hline & & Haplocryands & Alic (1), Typic (1) & 208 \\
\hline & \multirow{4}{*}{ Udands } & Durudands & Aquic (3), Typic (4) & 477 \\
\hline & & Fulvudands & Aquic (7), Eutric Pachic (5), Lithic (3), Oxyaquic (3), Pachic (19), Typic (40) & 8020 \\
\hline & & Hapludands & Alic (17), Aquic (1), Lithic (3), Oxyaquic (2), Typic (13), Vitric (3) & 3122 \\
\hline & & Melanudands & Typic (1) & 392 \\
\hline & Subtotal & & & 12,353 \\
\hline Entisols & Aquents & Cryaquents & Typic (1) & 19 \\
\hline & & Fulvaquents & Aeric (1), Typic (1) & 35 \\
\hline & Fluvents & Cryofluvents & Typic (1) & 362 \\
\hline & & Udifluvents & Oxyaquic (1), Typic (4), Vitrandic (1) & 197 \\
\hline & Orthents & Cryorthents & Lithic (1), Typic (1) & 30 \\
\hline & Psamments & Udipsamments & Typic (3) & 133 \\
\hline & Subtotal & & & 776 \\
\hline Histosols & Folists & Cryofolists & Lithic (1) & 1811 \\
\hline & Hemists & Haplohemists & Terric $(2)$ & 30 \\
\hline & Saprists & Cryosaprists & Lithic (3), Terric (1), Typic (1) & 3888 \\
\hline & & Haplosaprists & Hemic (1) & 43 \\
\hline & Subtotal & & & 5772 \\
\hline Inceptisols & Aquepts & Cryaquepts & Aeric (1), Histic (1), Histic Lithic (1) & 68 \\
\hline & & Endoaquepts & Fluvaquentic (3), Vertic (4) & 308 \\
\hline & & Epiaquepts & Aeric (1) & 25 \\
\hline & & Humaquepts & Aeric (1), Aquandic (1), Fluvaquentic (2), Typic (6) & 227 \\
\hline & & Petraquepts & Histic Placic (1), Typic (1) & 116 \\
\hline & Cryepts & Dystrocryepts & Andic (2), Lithic (1) & 40 \\
\hline & & Eutrucryepts & $\operatorname{Humic}(1)$ & 73 \\
\hline & Udepts & Dystrudepts & Andic (9), Andic Oxyaquic (4), Aquandic (3), Humic (19), Lithic (3), Oxyaquic (2), Typic (13) & 3042 \\
\hline & & Eutrudepts & Aquertic (1), Dystric (8), Lithic (3) & 1872 \\
\hline & & Fragiudepts & Andic (1), Typic (1) & 292 \\
\hline & & Humudepts & $\begin{array}{l}\text { Andic (21), Andic Oxyaquic (1), Aquandic (3), Aquic (1), Cumulic (1), Fluventic (3), Lithic (2), } \\
\text { Oxyaquic (2), Pachic (5), Psammentic (1), Typic (16) }\end{array}$ & 8739 \\
\hline & Ustepts & Dystrustepts & Humic (1), Lithic (1), Typic (1) & 35 \\
\hline & & Humustepts & Typic (1) & 25 \\
\hline & Xerepts & Dystroxerepts & Andic (3), Aquic (1), Typic (1), Vitrandic (1) & 1003 \\
\hline & Subtotal & & & 15,869 \\
\hline Mollisols & Aquolls & Endoaquolls & Cumulic (1), Fluvaquentic (2) & 29 \\
\hline & & Epiaquolls & Typic (1) & 1 \\
\hline & Udolls & Argiudolls & Aquic (2), Typic (2) & 21 \\
\hline & & Hapludolls & Typic (1) & 8 \\
\hline & Xerolls & Argiustolls & Pachic (1) & 6 \\
\hline & & Argixerolls & Pachic Ultic (1), Ultic (1) & 203 \\
\hline & & Haploxerolls & Cumulic Ultic (1), Lithic Ultic (1), Pachic Ultic (1), Ultic (1) & 181 \\
\hline & Subtotal & & & 449 \\
\hline Spodosols & Aquods & Cryaquods & Lithic (1), Typic (1) & 1789 \\
\hline & & Duraquods & Typic (3) & 55 \\
\hline & & Endoaquods & Typic (1) & 58 \\
\hline & & Epiaquods & Typic (1) & 5 \\
\hline & Cryods & Haplocryods & Typic (1) & 11 \\
\hline & & Humicryods & Lithic (5), Typic (9) & 9660 \\
\hline & Orthods & Durorthods & Typic (1) & 40 \\
\hline & & Haplorthods & Aquic (1), Entic (1), Oxyaquic (1), Typic (4) & 253 \\
\hline & Subtotal & & & 11,871 \\
\hline Ultisols & Aquults & Albaquults & Typic (1) & 4 \\
\hline & & Paleaquults & Umbric (1) & 20 \\
\hline & & Umbraquults & Typic (2) & 12 \\
\hline & Humults & Haplohumults & Andic (2), Aquic (1), Oxyaquic (2), Plinthic (1), Typic (25) & 2415 \\
\hline & & Kandihumults & Typic (2) & 40 \\
\hline & & Palehumults & Andic (1), Aquic (2), Oxyaquic (2), Typic (20), Xeric (3) & 3196 \\
\hline & Udults & Hapludults & Aquic (1), Lithic (1), Typic (3) & 97 \\
\hline & & Paleudults & Typic (1) & 78 \\
\hline & Ustalts & Haplustults & Typic (2) & 144 \\
\hline & Subtotal & & & 5862 \\
\hline Total: 8 & 30 & 66 & $142(482)$ & 55,989 \\
\hline
\end{tabular}


Table 3b

Soil taxa in coastal temperate rainforests of British Columbia, Canada. Data from BC Ministry of Environment (2013) and Centre for Land and Biological Resources Research (1996). Taxa are listed using the Canadian System of Soil Classification terminology, followed by approximate Soil Taxonomy equivalent for order and great groups. Number of unlisted sub-taxa appears in parentheses.

\begin{tabular}{|c|c|c|c|}
\hline Order & Great group & Subgroup & $\begin{array}{l}\text { Area } \\
{\left[\mathrm{km}^{2}\right]}\end{array}$ \\
\hline \multirow[t]{2}{*}{ Podzolic/Spodosols } & $\begin{array}{l}\text { Humo-Ferric } \\
\text { Podzols/Orthods }\end{array}$ & $\begin{array}{l}\text { Duric, Gleyed Ortstein, } \\
\text { Orthic, Ortstein, } \\
\text { Placic }\end{array}$ & 1700 \\
\hline & $\begin{array}{l}\text { Ferro-Humic } \\
\text { Podzols/Cryods }\end{array}$ & $\begin{array}{l}\text { Duric, Gleyed, } \\
\text { Gleyed Ortstein, } \\
\text { Orthic, Ortstein, Placic }\end{array}$ & 31,500 \\
\hline Organic/ & Fibrisols/Fibrists & Typic & 170 \\
\hline \multirow[t]{3}{*}{ Histosols } & Humisols/Hemists & Terric, Typic & 1250 \\
\hline & Mesisols/Saprists & Fibric, Terric, Typic & 1400 \\
\hline & Folisols/Folists & Humic, Typic & 7900 \\
\hline Gleysolic/ & - & - & 400 \\
\hline \multirow[t]{2}{*}{ aquic suborders } & $\begin{array}{l}\text { Gleysols/aquic } \\
\text { suborders }\end{array}$ & Orthic, Rego & - \\
\hline & $\begin{array}{l}\text { Humic Gleysols/ } \\
\text { aquic suborders }\end{array}$ & Orthic, Rego & - \\
\hline Others (3) & $\begin{array}{l}\text { Dystric Brunisols/ } \\
\text { Dystrocryepts (5), } \\
\text { Sombric Brunisol/ } \\
\text { Cryepts (1), } \\
\text { Regosol/Entisols (3), } \\
\text { Gray Luvisols/Udalfs (1) }\end{array}$ & - & $<100$ each \\
\hline Total: 6 & 12 & 33 & 44,300 \\
\hline
\end{tabular}

based on the most dominant component in a mapping unit, with dominance determined as the highest areal percentage component within vector landscape units.

To compare soils of the temperate rainforests of western North America with those of tropical rainforests, we summarized data for soil series in the Perox suborder from Micronesia in the Pacific Basin (National Cooperative Soil Survey, 2013; Soil Survey Staff, 2013b, 2013c). The Perox suborder was selected for comparison because the seasonal distribution of precipitation approximates that of temperate rainforests in the NAPC region.

\section{Results}

\subsection{Distribution of soil taxa}

Soils of the western North American temperate rainforest are represented by 8 orders and 31 suborders (or Canadian great groups; Tables $3 a$ and $b$ ). In the US portion of the region, there are 65 great groups and 142 subgroups (Table 3a), while in BC 33 Canadian subgroups have been identified (Table $3 \mathrm{~b}$ ). In the US databases there are 482 mapped soil series, accounting for $45 \%$ of the US portion and $33 \%$ of the entire study area, which we show here at the level of suborder (Fig. 2a and b).

Sixty-two of the 482 mapped soil series occur in the northwestern CA portion of the temperate rainforest, accounting for an area of $4550 \mathrm{~km}^{2}$ (38\% of MLRA 4B; Table 2). The soils are dominantly Ultisols (41\% of mapped soil area), followed by Alfisols (22\%), and Inceptisols (19\%; Fig. 2a). Coastal OR and WA contain 387 soil series that account for $33,921 \mathrm{~km}^{2}$ (84\% of MLRAs 1 and 4A), including Andisols (40\% of mapped soil area), Inceptisols (37\%), and Ultisols (12\%; Table 2; Fig. 2a). Soils in the BC rainforests are mapped to suborder (or Canadian great group; Fig. 2b). Western Vancouver Island is dominated by Podzolic soils (i.e. Spodosols; 85\%), while the Coastal Gap ecoregion contains both Podzols (50\%) and Organic soils (i.e. Histosols; 48\%), as does Gwaii Haanas (83\% and 16\% respectively; Table 2). Only a small portion of the Gulf of Alaska Coast (MLRA 220) has been mapped, with 24 soil series recognized to date accounting for $17,732 \mathrm{~km}^{2}(25 \%$ of the total area; Table 2; Fig. 2c). Five soil subgroups comprise $53 \%$ of the total mapped area of the US temperate rainforests: Typic Humicryods $\left(5180 \mathrm{~km}^{2}\right)$, Lithic Humicryods $\left(4129 \mathrm{~km}^{2}\right)$, Typic Fulvudands $\left(4098 \mathrm{~km}^{2}\right)$, Terric Cryosaprists $\left(1963 \mathrm{~km}^{2}\right)$, and Lithic Cryosaprists $\left(1864 \mathrm{~km}^{2}\right)$.

\subsection{Soil characteristics}

Temperate rainforest soils in CA, OR and WA are deep $(100-150 \mathrm{~cm})$ to very deep $(>150 \mathrm{~cm})$ in terms of potential rooting, while those in coastal BC and southeastern AK are moderately deep (50-100 cm; Table 2). While there is considerable variation in drainage class within an MLRA, overall, the soils tend to be moderately well-drained to well-drained. The dominant soil-temperature regime varies with latitude, being isomesic (mean annual soil temperature at $50 \mathrm{~cm}$ ranges between 8 and $15{ }^{\circ} \mathrm{C}$ and the difference between the mean summer and winter temperature is $<6{ }^{\circ} \mathrm{C}$ ) in the Sitka Spruce and Coastal Redwood Belts (MLRAs 4B and 4A), mesic in the Northern Pacific Coast Range, isomesic to isofrigid or cryic in coastal BC, and cryic (mean annual soil temperature ranges between 0 and $8{ }^{\circ} \mathrm{C}$ without permafrost) along the Gulf of Alaska Coast. The dominant soil moisture regime is udic (no sustained period of drought), with an aquic regime also found in most subregions.

Soils in NAPC rainforests tend to occur in the finer particle-size classes, but often have abundant coarse fragments (Table 2). In CA the soils are mostly fine-loamy or loamy, while in OR and WA they are most commonly medial or medial-skeletal (volcanically derived soils with $>35 \%$ coarse fragments). In coastal BC and southeast AK soils tend to fall into the organic or loamy- to sandy-skeletal size classes. Whereas soils in coastal CA, BC and AK often have a mixed mineralogy, those in western OR and WA are derived from volcanic materials and commonly have a ferrihydritic (abundant amorphous and organic-bound $\mathrm{Fe}$ ) or isotic (abundant allophane) mineralogy. Although $43 \%$ of the soil series in temperate rainforests of northern CA are superactive (i.e., the ratio of the cation-exchange capacity (CEC) as determined from $\mathrm{pH} 7$ ammonium acetate to clay is $\geq 0.6$ ), soils elsewhere in the temperate rainforest of western North America contain less active clays.

The most common diagnostic surface and subsurface horizons in soils of the CA temperate rainforest are ochric and argillic, which average 33 and $91 \mathrm{~cm}$ in thickness, respectively (Table 2). Umbric or ochric and cambic horizons are most common in western OR and WA, averaging 30 to 38 and 67 to $71 \mathrm{~cm}$, respectively. In coastal BC and AK, histic and spodic horizons are most common and average more than $>20$ $\mathrm{cm}$ and $>10 \mathrm{~cm}$ in thickness, respectively (Table 2). Fig. 3 shows examples of coastal temperate rainforest soils, including a sandy, mixed, isomesic, ortstein, shallow Typic Duraquods (Blacklock soil series) from coastal Oregon, a fine, mixed, superactive, isomesic Typic Palehumults (Cunniff soil series) from coastal Oregon, a Humo-Ferric Podzol (Haplorthods) from coastal British Columbia, and a Lithic Humicryods from Port Graham, Alaska.

\subsection{Soil analytic properties}

We assembled analytical data for 27 soil series that are representative of the land area and taxonomic classes of soils in coastal temperate rainforests of western North America (Table 4, Fig. S1). Where possible these data were evaluated in comparison with values reported in the global datasets of Batjes (1997) and Post et al. (1985). Soils in NAPC rainforests tend to be moderately deep (MN: $122 \mathrm{~cm}$, IQR: 86-150 $\mathrm{cm}$ ) with bulk densities that are comparatively low overall (MN: $1.18 \mathrm{~g} / \mathrm{cm}^{3}$ ), but range widely (IQR: $0.91-1.42 \mathrm{~g} / \mathrm{cm}^{3}$ ) with extremes of 0.40 and $1.60 \mathrm{~g} / \mathrm{cm}^{3}$, the higher values from soils with ortstein horizons. These soils have fairly high CEC (MD: $33.1 \mathrm{cmol}_{\mathrm{C}} / \mathrm{kg}$, IQR: 16.9-41.2), but low effective CEC, base saturation (MD: 7\%, IQR: 3-30), exchangeable cation concentration ( $\mathrm{MN}: 2.3 \mathrm{cmol}_{\mathrm{c}} / \mathrm{kg}$, IQR: 1.5-4.8) and pH (MN: 5.0, IQR: 4.6-5.3; Table 4). Soils in this region 
can be Al-saturated (MN: 54\%, IQR: 32-78) and are commonly enriched in extractable Fe and $\mathrm{Al}$.

Profile quantities (to $100 \mathrm{~cm}$ ) of SOC, total N, and exchangeable cations all exhibit right-skewed distributions in NAPC rainforests with a small number of very high values (Fig. 4; Table 4). Exchangeable base cation storage was mostly clustered around the median of $165 \mathrm{kmol}_{\mathrm{c}} /$ ha (IQR: 89-315 $\mathrm{kmol}_{\mathrm{c}} / \mathrm{ha}$ ), but had a wide range, with two extremely high values (1256 and $2035 \mathrm{kmol}_{\mathrm{c}} / \mathrm{ha}$ ) indicating a particularly skewed distribution. SOC storage is variable (IQR: $116-439 \mathrm{Mg} / \mathrm{ha}$ ), but generally high, with a median of $211 \mathrm{Mg} \mathrm{C} / \mathrm{ha}$. Storage of total N follows a similar pattern as SOC, with large variability (IQR: 7384-26,013) and a high median of $15,113 \mathrm{~kg} / \mathrm{ha}$, but with more large values. The highest SOC and total $\mathrm{N}$ values came from the same pedons, a Lithic Cryosaprist near Ketchikan, AK (1050 Mg C/ha, 44,385 kg N/ha), and a Typic Fulvudand near Grays Harbor, WA (763 Mg C/ha, 39,241 kg N/ha). C to N ratios were more normally distributed, with a fairly high mean of 18.4 and an interquartile range between 13.8 and 21.2.

\section{Discussion}

\subsection{Pedodiversity}

A key finding of this study is that the soils of NAPC temperate rainforests are exceedingly diverse. In the US, Pacific coastal rainforests contain 8 orders, 30 suborders, 65 great groups, and 142 subgroups, in addition to 482 soil series (Table $3 a$ ); coastal BC contains 6 Canadian soil orders, 12 great groups and 33 subgroups (Table $3 \mathrm{~b}$ ). Using the soil taxa richness-area relationships found by Guo et al. (2003), one would predict 7 orders, 17 suborders, 43 great groups, 125 subgroups, and 386 series in the US portion of our study region. The consistently greater number of taxa that we found means that at least in terms of soil taxa richness, NAPC rainforests have higher than expected pedodiversity. Guo et al. (2003) found that the western US as a whole has among the highest pedodiversities across a number of taxonomic scales, compared to other regions of the country. Using coarse climate a

\section{DOMINANT SOILS} MLRAs 1, 4A \& 4B

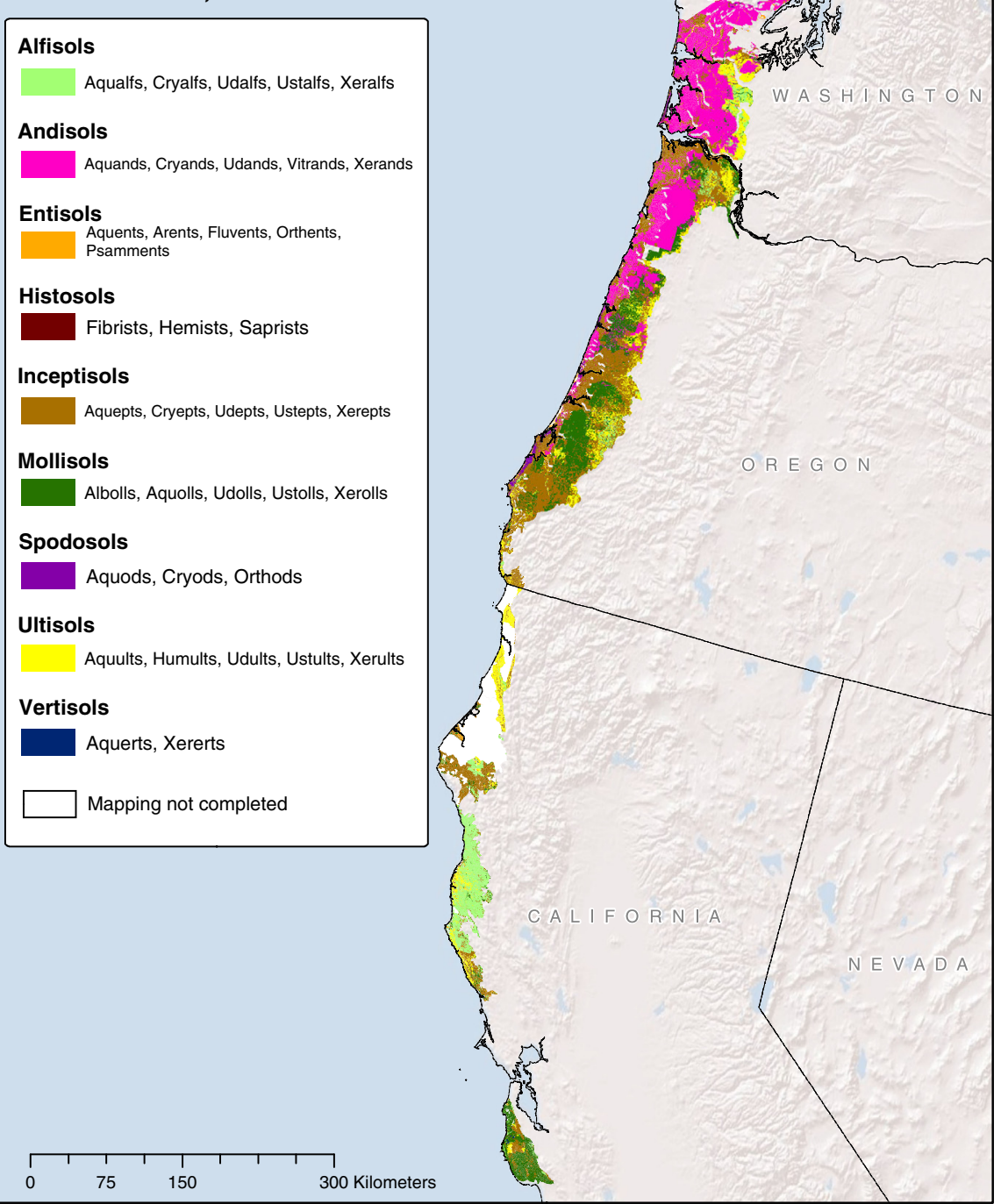

b

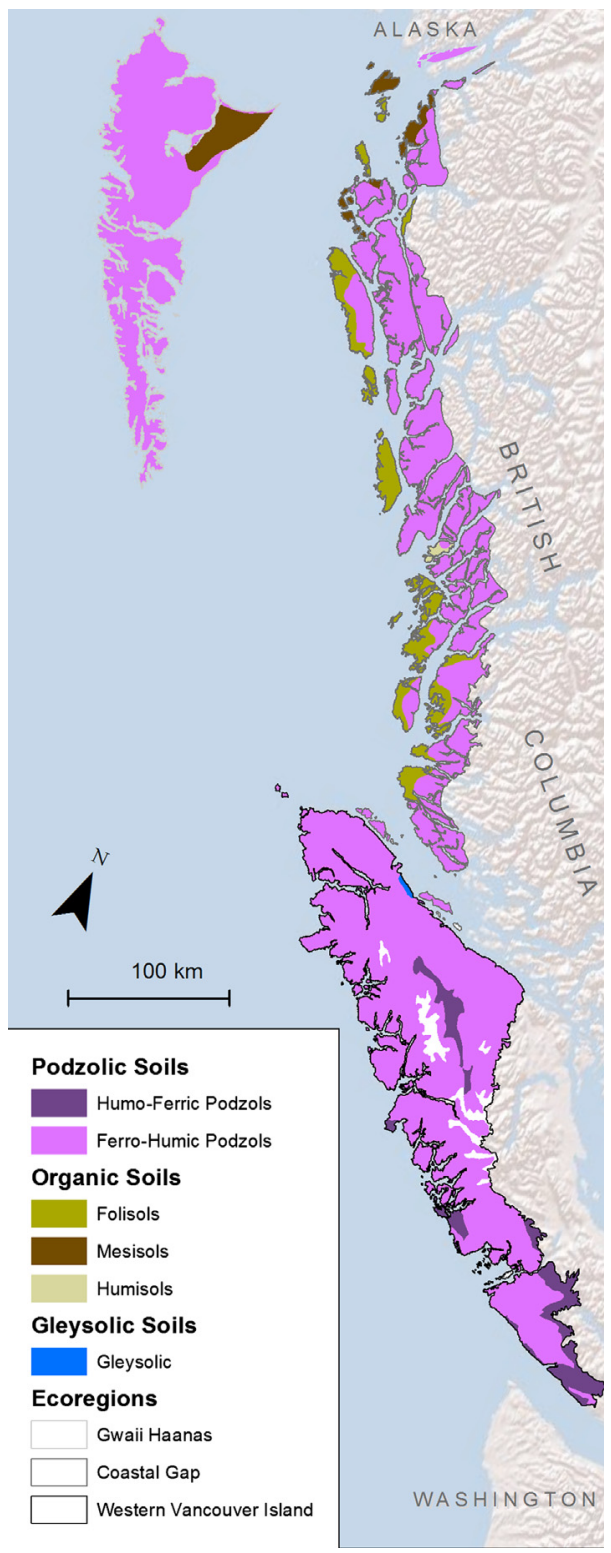

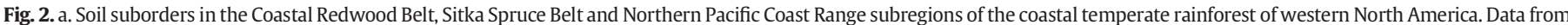

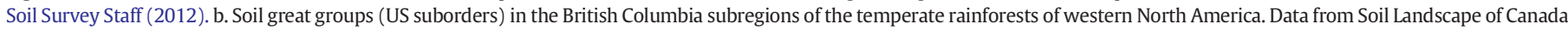

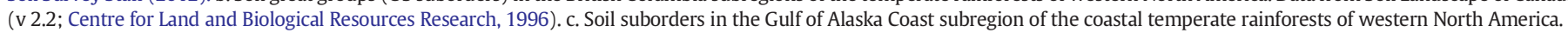
Data from Soil Survey Staff (2012). 
C

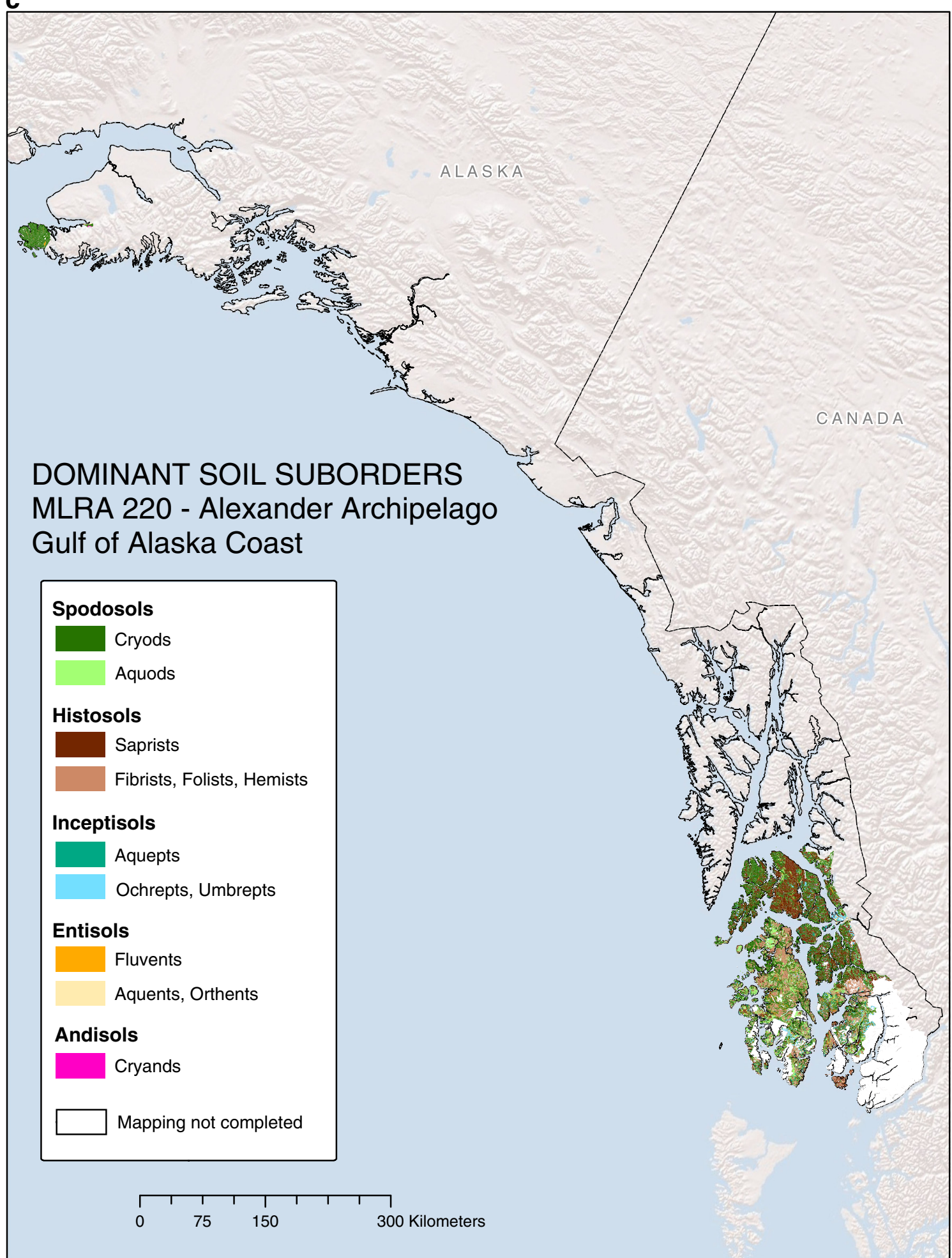

Fig. 2 (continued).

zones and World Reference Base soil groups at a global scale, Minasny et al. (2010) suggest that areas with moderate temperatures and precipitation regimes have greater pedodiversity and taxonomic differentiation, but our findings indicate that a region with moderate temperatures and high levels of precipitation can also have highly diverse soils.
One feature of pedodiversity is soil endemism. Bockheim (2005) identified endemic soils on the basis of having a centralized distribution, lacking competing soil series, and being unique to a particular area. Based on these criteria, $26 \%$ of the 482 soil series are endemic to temperate rainforests of the western US (listed in Supplement S2). The proportion of endemic soils varies by latitude (Fig. 5), and accordingly by mean 

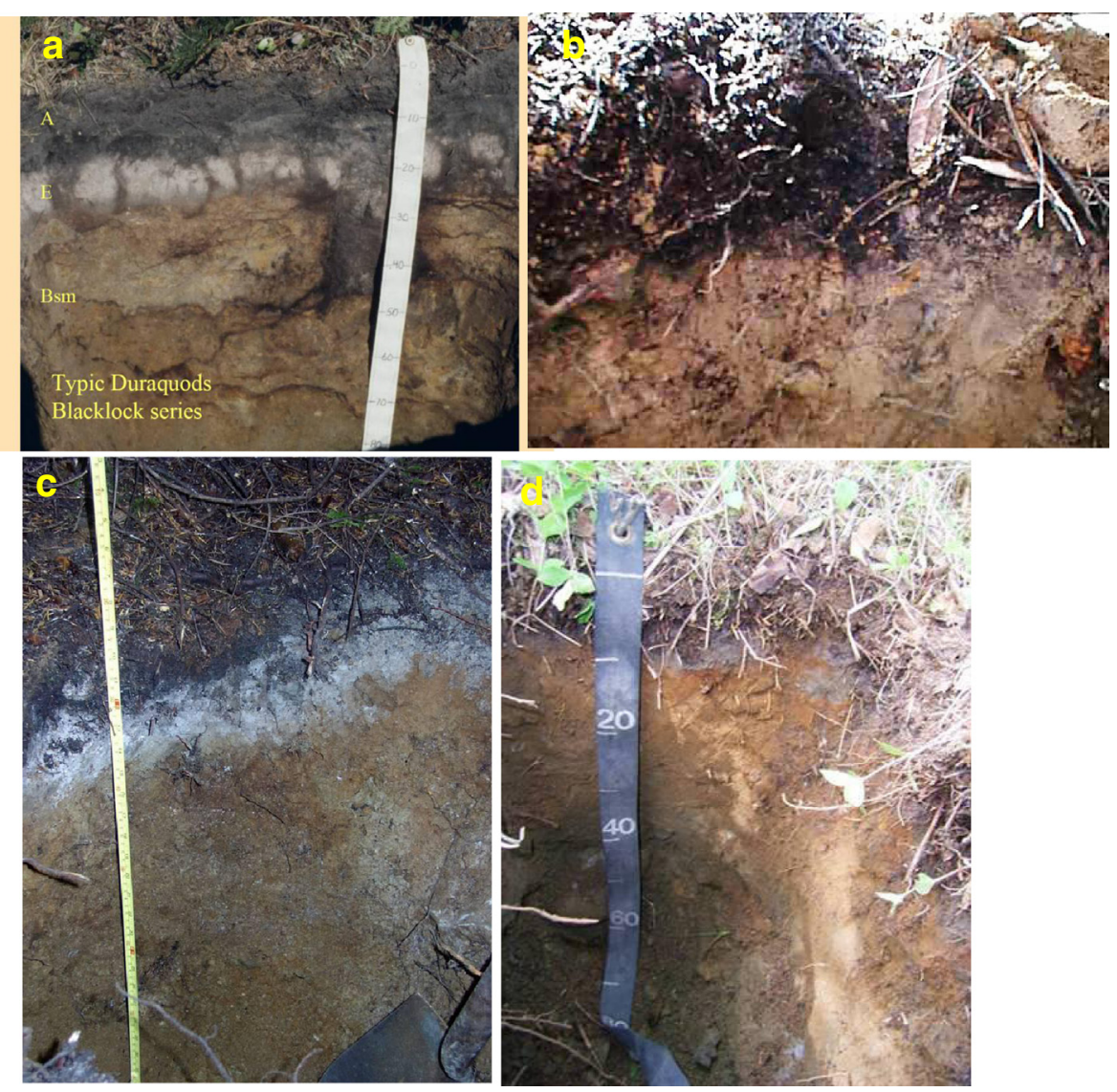

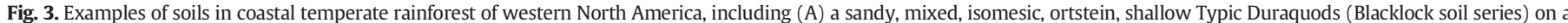

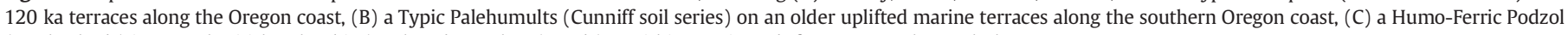
(Haplorthods) in coastal British Columbia (Paul Sanborn photo), and (D a Lithic Humicryods from Port Graham, Alaska.

NRCS photo.

annual precipitation and temperature, with the greatest proportion of endemic soils occurring in the Coastal Redwood Belt ( $42 \%$ of soil series) and the least along the Gulf of Alaska Coast (5\%). The reason for the lower pedodiversity along the Gulf of Alaska may relate to the young age of these soils and the uniformly cool, wet conditions of forests that are restricted to a narrow strip along the coast at these latitudes.

The range of parent materials, topography, mesoclimates, and pedogenic histories that are found in NAPC rainforests are all likely to contribute to the regional pedodiversity and soil endemism. Pedodiversity in the Pacific temperate rainforests may be enhanced by episodic tephra deposition (Briggs et al., 2006) and the variation in ages of landscapes from glacial recession (Bormann and Sidle, 1990; Crocker and Dickson, 1957; Ugolini, 1968) and exposure of raised beaches (Bockheim et al., 1996; Singleton and Lavkulich, 1987). Soil parent materials in southeastern $\mathrm{AK}$, coastal $\mathrm{BC}$, and northern WA were deposited during the last glacial period 13-16,000 yr BP (Mann and Hamilton, 1995), while soil parent materials in northern CA and southern OR can be hundreds of thousands of years old (Bockheim et al., 1996; Merritts et al., 1991). Though the NAPC and other temperate rainforest regions have broadly similar temperature and precipitation regimes from a global perspective, they still contain considerable climatic heterogeneity (Table 2; Alaback, 1991; Lawford et al., 1995). Subregion-scale differences in climate are further modified by gradients of oceanic influence and the topographic complexity of the Pacific Coast Ranges, and this mesoclimatic variation can have a significant effect on soil formation (Briggs et al., 2006). We believe that further investigation is warranted to more fully understand the relationships between pedodiversity, climate, and other factors of soil formation in temperate rainforests and other bioregions.

\subsection{Soil properties in temperate rainforests}

\subsubsection{Soil carbon}

One of the most striking aspects of NAPC temperate rainforest soils is their propensity for storing large quantities of organic $C$. Median organic C storage in the soils that we examined $(211 \mathrm{Mg} / \mathrm{ha})$ falls within the range of median values (143-289 Mg/ha) reported in other studies in the region (Table 5), and is substantially higher than that reported for other regions of the United States (60-100 Mg/ha; Homann et al., 2007). The values reported in Table 5 are likely underestimates of actual $\mathrm{SOC}$, as they generally do not include soil $\mathrm{C}$ from the $>2 \mathrm{~mm}$ fraction of soils, which has been found contain up to $46 \%$ additional SOC in oldgrowth forests in the Pacific Northwest (Homann et al., 2004). Broadscale studies of soil C in Pacific temperate rainforests consistently report higher SOC values than the estimate of Post et al. (1985) for cool temperate rainforest globally (154 Mg/ha; Table 5), as well as for wet tropical forests (132 Mg/ha). Our estimate is closer to Post et al.'s (1985) for warm and subtropical wet forests (226 Mg/ha), but still below that for boreal rainforests $(288 \mathrm{Mg} / \mathrm{ha})$. A number of life zones included in Post et al.'s (1985) dataset have small sample sizes and may not adequately capture intra-zone heterogeneity, but temperate rainforests are clearly among the top bioregions in terms of SOC.

Climate, vegetation dynamics, disturbance history, decomposition rates, soil development, and the quantity and quality of dead organic matter all play a role in SOC storage in temperate rainforests. High SOC concentrations are known to be associated with regions of low moisture deficit, as in NAPC rainforests (Homann et al., 2007). Mild temperatures and abundant precipitation create highly favorable conditions for biomass production by long-lived conifers (Waring and Franklin, 
Table 4

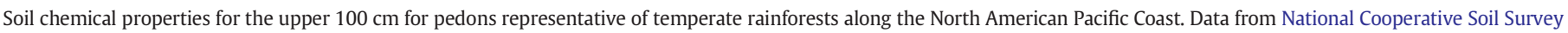
(2013). Additional physical and chemical data can be found in Supplement 1.

\begin{tabular}{|c|c|c|c|c|c|c|c|}
\hline Pedon no. & Subgroup & Location & $\mathrm{pH}$ & Exch. bases $[\mathrm{kmol}(+) / \mathrm{ha}]$ & $\mathrm{SOC}[\mathrm{Mg} / \mathrm{ha}]$ & Total N [kg/ha] & $\mathrm{C}: \mathrm{N}$ ratio \\
\hline 80Р0452 & Mollic Hapludalfs & Mendocino, CA & 5.9 & - & - & - & - \\
\hline $80 \mathrm{P} 0445$ & Ultic Hapludalf & Mendocino, CA & 5.4 & 639 & 112 & 6178 & 18.1 \\
\hline $80 \mathrm{P} 0449$ & Ultic Haplustalf & Mendocino, CA & 5.5 & 2035 & 88 & 6557 & 13.5 \\
\hline 84P0900 & Alic Fulvudand & Lincoln, OR & 4.8 & 123 & 435 & 25,680 & 16.9 \\
\hline $72 C 0055$ & Typic Fulvudand & Douglas, OR & 5.2 & 335 & 518 & 27,014 & 19.2 \\
\hline 84P0905 & Typic Fulvudand & Grays Harbor, WA & 4.7 & 168 & 793 & 39,241 & 20.2 \\
\hline 78Р0393 & Typic Fulvudand & Grays Harbor, WA & 5.0 & - & - & - & - \\
\hline 98P0536 & Pachic Fulvudand & Grays Harbor, WA & 4.3 & 31 & 205 & 9135 & 22.4 \\
\hline $82 \mathrm{P} 0545$ & Lithic Cryofolist & Wrangell-Petersburg, AK & 3.9 & - & - & - & - \\
\hline 83Р0826 & Lithic Cryosaprist & Ketchikan, AK & 6.3 & - & 1050 & 44,385 & - \\
\hline $40 A 0647$ & Lithic Cryosaprist & Wales, AK & 3.9 & - & - & - & - \\
\hline 84P0141 & Terric Cryosaprist & Ketchikan, AK & 4.8 & 78 & 450 & 23,552 & 19.1 \\
\hline 40A2989 & Typic Dystrochrept & San Mateo, CA & 5.9 & - & 35 & - & - \\
\hline 01N1071 & Andic Dystrudept & Tillamook, OR & 5.2 & 203 & 455 & 32,042 & 14.2 \\
\hline $72 C 0057$ & Andic Humudept & Coos, OR & 5.2 & 1256 & 163 & 13,242 & 12.3 \\
\hline 74C0145 & Typic Humudept & Coos, OR & 5.5 & 256 & 284 & 21,814 & 13.0 \\
\hline $90 \mathrm{P} 0072$ & Histic Placic Petraquept & Grays Harbor, WA & 5.3 & - & - & - & - \\
\hline 74C0148 & Typic Duraquod & Coos, OR & 4.7 & 96 & 217 & 9199 & 23.6 \\
\hline $74 C 0147$ & Typic Haplorthod & Coos, OR & 5.2 & 88 & 194 & 11,248 & 17.2 \\
\hline 74C0149 & Typic Haplorthod & Coos, OR & 5.2 & 229 & 235 & 16,985 & 13.8 \\
\hline 82P0618 & Lithic Humicryod & Haines, AK & 4.5 & 91 & 163 & 7384 & 22.1 \\
\hline $82 \mathrm{P} 0547$ & Lithic Humicryod & Wrangell-Petersburg, AK & 3.8 & - & - & - & - \\
\hline 82P0617 & Typic Humicryod & Haines, AK & 4.9 & 161 & 217 & - & - \\
\hline $40 A 0623$ & Typic Humicryod & Prince of Wales, AK & 4.4 & 19 & 154 & 5089 & 30.2 \\
\hline 83Р0072 & Typic Humicryod & Wrangell-Petersburg, AK & 4.6 & - & - & - & - \\
\hline 92P1058 & Typic Haplohumult & Curry, OR & 5.0 & 101 & 116 & - & - \\
\hline $40 \mathrm{~A} 3077$ & Typic Haplustult & Sonoma, CA & 6.0 & 634 & 51 & - & - \\
\hline Minimum & & & 3.8 & 19 & 35 & 5089 & 12.3 \\
\hline 25th percentile & & & 4.6 & 89 & 116 & 7384 & 13.8 \\
\hline Median & & & 5.0 & 165 & 211 & 15,113 & 18.1 \\
\hline Mean & & & 5.0 & 363 & 297 & 18,672 & 18.4 \\
\hline 75th percentile & & & 5.3 & 315 & 439 & 26,013 & 21.2 \\
\hline Maximum & & & 6.3 & 2035 & 1050 & 44,385 & 30.2 \\
\hline
\end{tabular}

1979), while cool, moist climate through much of the year results in low decomposition rates under the oxygen-limited conditions of wet soils (Schuur et al., 2001). Sun et al. (2004) suggest that high SOC levels in coastal OR may be caused by abundant precipitation increasing microbial activity and decomposition in the forest floor, where oxygen is rarely limiting, while retarding decomposition in the more poorly aerated mineral soil. Restricted drainage resulting from podsolization and paludification can lead to the development of thick, C-dense, organic layers, particularly in more northern NAPC rainforests. Even when podsolization does not lead to water-logged conditions, the translocation of Fe and Al can play an important role in SOC stabilization in the mineral layers of temperate rainforest Spodosols by forming organometallic complexes, among other mechanisms (Grand and Lavkulich, 2012).

The accumulation of SOC is an important component of total ecosystem C storage, which is exceptionally high in temperate rainforests, even more so than SOC alone (Keith et al., 2009; Smithwick et al., 2002). In western OR and WA, total ecosystem $C$ has been found to strongly correlate with SOC $<2 \mathrm{~mm}$ in the upper $20 \mathrm{~cm}$ of mineral soil (Homann et al., 2005). However, the mechanisms and duration of net SOC accumulation during ecosystem development are not always clear. Bormann et al. (1995) found no evidence of SOC reaching equilibrium over a 350 year chronosequence in southeast $\mathrm{AK}$, but for forests in western OR, SOC content appears to reach an asymptote 150 to 200 years after stand initiation (Sun et al., 2004). Differences in disturbance type and severity, as well as climate, likely play a role. Several studies have documented the importance of windthrow in soil $\mathrm{C}$ dynamics, as the uprooting of trees disrupts podsolization and redistributes organic matter within a soil profile, with potentially positive effects for forest productivity (Bormann et al., 1995; Kramer et al., 2004). Soil chronosequences also show rapid accumulation of SOC in temperate rainforests undergoing primary succession (Bockheim et al., 1996; Burt and Alexander, 1996; Singleton and Lavkulich, 1987).
Though SOC levels were generally high, we also found considerable variability among soils in NAPC rainforests, which may reflect the high pedodiversity and varied soil development processes in the region. The IQR of SOC was considerably larger in our sample of temperate rainforest soils compared to other regional studies and estimates for rainforests globally (Table 5). Our sample was designed to capture the full range of soil types in the bioregion, while the others are more restricted. The distribution of SOC in the pedons that we examined was notably right-skewed, with a modal value of $\sim 200 \mathrm{Mg} / \mathrm{ha}$, and a small number of soils containing exceptionally large amounts of carbon (Fig. 5). A similar distributional pattern was noted by Post et al. (1982), and may be a common feature of SOC distributions at broad scales, in which case standard summary statistics of untransformed SOC data (e.g. mean and standard deviation) may be misleading.

There was a notable increase in SOC content, and particularly concentration (i.e. \% SOC) with latitude within NAPC rainforests. The soils that we found with the lowest SOC were Haplustults, Haplohumults, and Hapludalfs in CA and southern OR, where summer moisture deficits are the highest in the region. In contrast, the abundant $\mathrm{SOC}$ in coastal $\mathrm{BC}$ and southeastern AK soils can be attributed to the gentle relief, slow rates of decomposition, and a high water table. Paludification is an important soil development process in this area. Translocated Fe and $\mathrm{Al} \mathrm{ac-}$ cumulates to form placic horizons, restricting drainage, raising the water table, and allowing C-rich organic horizons to form, often leading to the conversion of ecosystems from forests to bogs (Klinger, 1996; Turunen and Turunen, 2003; Ugolini and Mann, 1979).

Several other factors have been associated with SOC variation at smaller scales in NAPC temperate rainforests. SOC is positively associated with soil water holding capacity, coarse woody debris, and clay content (Homann et al., 2004, 2007). Vegetation and forest type have been observed to correlate with SOC (Edmonds and Chappell, 1994), as has parent material, with higher soil C concentration found on sedimentary 

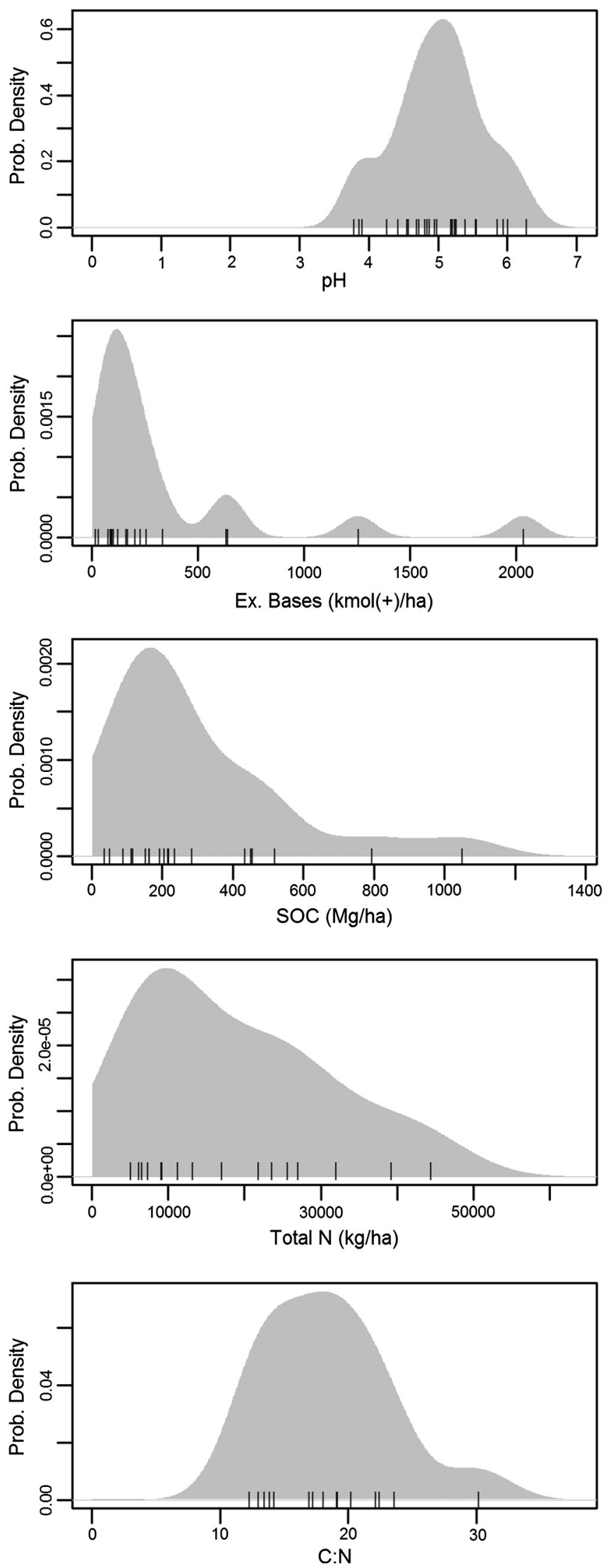

Fig. 4. Distribution of soil chemical properties among representative pedons in North American coastal temperate rainforests. Individual observations are displayed as ticks, while the probability density was generated using a kern density function in the R statistical environment.

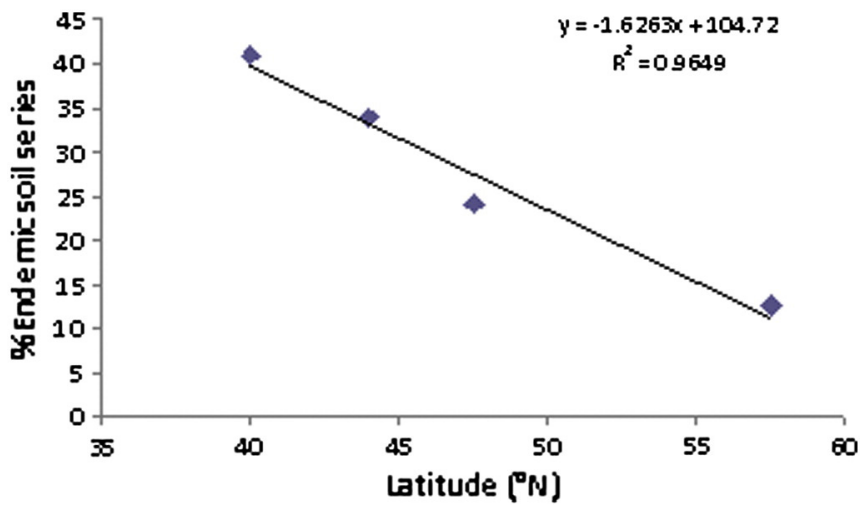

Fig. 5. Relationship between the proportion of endemic soil series and latitude in coasta temperate rainforests of western North America.

rock in the Pacific Northwest (Littke et al., 2011). Heterogeneity in SOC can be influenced by topography and hydrology, particularly in the forest-peatland complexes of coastal $\mathrm{BC}$ and $\mathrm{AK}$, where $\mathrm{C}$ dynamics can be highly variable and soil properties are not necessarily directly coupled with vegetation (D'Amore et al., 2010; Hartshorn et al., 2003).

\subsubsection{Soil nitrogen and carbon to nitrogen ratio}

As with SOC, total soil $\mathrm{N}$ pools tend to be large in temperate rainforests of the NAPC, though they are also highly variable. Median total $\mathrm{N}$ in the pedons that we examined $(15,113 \mathrm{~kg} / \mathrm{ha})$ is similar to values reported by Perakis and Sinkhorn (2011) and Smithwick et al. (2002) and higher than that reported by Edmonds and Chappell (1994) and Littke et al. (2011; Table 5). The levels of soil $\mathrm{N}$ that we found are higher than has been reported globally for temperate rainforests and for most other bioregions, with the exception of warm temperate and subtropical wet forests and rain tundra (Post et al., 1985; Table 5). We also found considerable variability in soil N (IQR: $7384-26,013 \mathrm{~kg} / \mathrm{ha}$ ), more so than in other studies (Table 5). Like SOC, soil N exhibits a right-skewed distribution, but with a much fatter tail; modal soil $\mathrm{N}$ is $\sim 10,000 \mathrm{~kg} / \mathrm{ha}$, but seven of sixteen in pedons that we examined had $\mathrm{N}$ over $20,000 \mathrm{~kg} / \mathrm{ha}$ (Fig. 5). NAPC rainforest soils with higher $\mathrm{N}$ concentration and content tend to be from the Andisol and Histisol orders, while those with lower $\mathrm{N}$ were often Alfisols and Spodosols, though a small sample size makes these observations tentative.

Soil $\mathrm{N}$ tends to be positively correlated with precipitation and clay content, though in the Pacific Northwest silt content appears to be more important than clay (Homann et al., 2007).

Studies on the OR Coast Range show great heterogeneity in $\mathrm{N}$ availability, with at least some forests that are $\mathrm{N}$-saturated (Perakis and Sinkhorn, 2011; Perakis et al., 2011).

Nitrogen-fixing tree species, particularly Alnus spp., play an important role in $\mathrm{N}$ dynamics, nutrient uptake, and forest productivity during both primary succession (Bormann and Sidle, 1990) and in secondary forests, where red alder fixes significant amounts of $\mathrm{N}$ (Compton et al., 2003; Perakis et al., 2011).

Nitrogen immobilization in vegetation, soil microbes, and in $\mathrm{O}$ and Bh horizons are considered high in these ecosystems (Bormann and Sidle, 1990; Bormann et al., 1995).

In older soils, labile forms of $\mathrm{N}$ may become deficient in temperate rainforests, as in 120,000 year-old end members of a soil chronosequence in New Zealand (Menge et al., 2011).

${ }^{15} \mathrm{~N}$ isotope studies show that important processes in bioavailable $\mathrm{N}$-cycling in temperate rainforests (volcanic soils) include heterotrophic production of inorganic $\mathrm{N}, \mathrm{N}$ immobilization by microbes, and leaching loss of organic $\mathrm{N}$, rather than inorganic $\mathrm{N}$ (Huygens et al., 2008). 
Table 5

Organic carbon and total nitrogen stores in soils of temperate rainforests in western North America.

\begin{tabular}{|c|c|c|c|c|c|c|}
\hline Location & $\mathrm{SOC}[\mathrm{Mg} / \mathrm{ha}]$ & Total N [kg/ha] & $\mathrm{C} / \mathrm{N}$ ratio & $\begin{array}{l}\text { No. of sites } \\
\text { (no. of } \\
\text { pedons) }\end{array}$ & Unit of analysis & Reference \\
\hline $\begin{array}{l}\text { Coastal Oregon, Washington, } \\
\text { northern California, } \\
\text { \& southeastern Alaska }\end{array}$ & $211(116-439)$ & $15,113(7384-26,013)$ & $18.4(13.8-21.2)$ & $\begin{array}{l}\text { SOC: } 20(20) \\
\mathrm{N}, \mathrm{C} / \mathrm{N}: 16(16)\end{array}$ & $\begin{array}{l}\text { Soil pedons throughout } \\
\text { the US coastal temperate } \\
\text { rainforests }\end{array}$ & $\begin{array}{l}\text { This study and } \\
\text { National Cooperative } \\
\text { Soil Survey (2013) }\end{array}$ \\
\hline $\begin{array}{l}\text { Pacific Northwest (western OR, } \\
\text { WA, southern BC) }\end{array}$ & $143(71-201)^{*}$ & $9141(4726-14,020)^{*}$ & $17(15-19)^{*}$ & $60(60)$ & $\begin{array}{l}\text { Douglas-fir plantations } \\
\text { grouped by soil nutrient } \\
\text { regimes ( } 3 \text { ) and parent } \\
\text { material (3) }\end{array}$ & Littke et al. (2011) \\
\hline Coastal Oregon \& Washington & $223(124-309)^{*}$ & $11,710(5642-15,220)^{*}$ & $20.3(19.3-23.5)^{*}$ & $53(53)$ & $\begin{array}{l}\text { Second-growth Douglas-fir } \\
\text { and western hemlock stands, } \\
\text { grouped by forest type and } \\
\text { subregion (5) }\end{array}$ & $\begin{array}{l}\text { Edmonds and } \\
\text { Chappell (1994) }\end{array}$ \\
\hline Coastal Oregon \& Washington & $289(210-362)$ & $16,000(\mathrm{NA})$ & 16.6 (NA) & $15(31)$ & $\begin{array}{l}\text { Mature western hemlock-Sitka } \\
\text { spruce stands in (15) at two } \\
\text { locations. }\end{array}$ & $\begin{array}{l}\text { Remillard (1999) and } \\
\text { Smithwick et al. (2002) }\end{array}$ \\
\hline Coastal Oregon & $268(211-297)$ & $15,890(14.360-18,760)$ & $16.7(14.4-17.9)$ & $10(40)$ & $\begin{array}{l}\text { Second-growth Douglas-fir } \\
\text { stands ( } 9 \text { ) with Andisc soil } \\
\text { properties on sandstone } \\
\text { parent material }\end{array}$ & $\begin{array}{l}\text { Sinkhorn (2007) and } \\
\text { Perakis and Sinkhorn } \\
(2011)\end{array}$ \\
\hline Coastal southeastern Alaska & $194(157-216)^{*}$ & NA & NA & $3(434)$ & $\begin{array}{l}\text { Western hemlock-Sitka spruce } \\
\text { stands in watersheds ( } 3 \text { ) with } \\
\text { different disturbance histories }\end{array}$ & Kramer et al. (2004) \\
\hline Cool temperate rainforests & $154(136-199)$ & $11,490(8595-13,630)$ & $15.3(13.6-17.0)$ & $\begin{array}{l}\text { SOC: } 17 \\
\mathrm{~N}, \mathrm{C} / \mathrm{N}: 14\end{array}$ & $\begin{array}{l}\text { Holdridge terrestrial } \\
\text { Life-zones of the } \\
\text { world; samples } \\
\text { from various } \\
\text { sources; naturally } \\
\text { vegetated sites }\end{array}$ & $\begin{array}{l}\text { Post et al. (1985), } \\
\text { Zinke et al. (1998) }\end{array}$ \\
\hline $\begin{array}{l}\text { Warm temperate/subtropical } \\
\text { wet forests }\end{array}$ & $226(187-293)$ & $16,980(13,120-19,840)$ & $14.7(12.1-17.2)$ & $\begin{array}{l}\text { SOC: } 53 \\
\text { N, C/N: } 52\end{array}$ & & \\
\hline Tropical wet forests & $132(79-196)$ & $6320(4562-8555)$ & $28.0(20.5-39.1)$ & $\begin{array}{l}\text { SOC: } 23 \\
\text { N, C/N: } 14\end{array}$ & & \\
\hline Boreal rainforests & $288(147-349)$ & $11,440(4140-14,110)$ & $25.8(19.1-28.8)$ & $\begin{array}{l}\text { SOC: } 23 \\
\text { N, C/N: } 21\end{array}$ & & \\
\hline
\end{tabular}

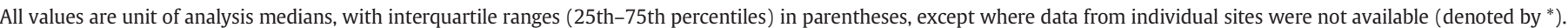

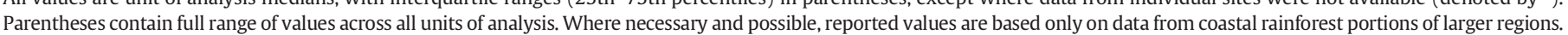

Tight N coupling in temperate rainforests results from "fierce" competition for bioavailable $\mathrm{N}$ by abiotic processes, soil microbes, and plant roots (Huygens et al., 2008).

It is generally assumed that ecosystem $\mathrm{N}$ is derived from atmospheric fixation, but recent work has shown bedrock as a potential source of soil N (Morford et al., 2011) and this may be the case in NAPC rainforests, where sedimentary parent materials have been correlated with higher soil N (Littke et al., 2011).

Typical C: $\mathrm{N}$ ratios in Pacific temperate rainforest soils appear to be around 18, based on our analysis and that of others (Table 5; Homann et al., 2007). This is higher than has been reported for temperate rainforests globally, and is higher than in other regions of the US and in most of the world's bioregions, with the exception of wet tropical forests, boreal rainforests, and tundra (Homann et al., 2007; Post et al., 1985; Table 5). Thus, while both SOC and soil N are high in NAPC temperate rainforests, high C:N ratios imply that SOC levels are generally more exceptional. The representative pedons that we examined have $\mathrm{C}: \mathrm{N}$ ratios with an approximately normal distribution, and though they were more variable than demonstrated by other studies in the region (Table 5), such variability does not appear to be atypical of bioregions globally (Post et al., 1985). High C:N ratios are associated with high levels of precipitation and lower temperatures, decomposition rates, silt and clay content, and litter quality, the latter being prevalent in coniferous forests (Homann et al., 2007; Post et al., 1985). In the Pacific Northwest, glacial parent material also tends to be correlated with higher C:N ratios (Littke et al., 2011).

\subsubsection{Other soil properties and characteristics}

Soils in NAPC temperate rainforests are moderately deep, welldrained, have abundant weatherable minerals (based on mineral classes), are not subject to deep freezing, and are able to hold abundant moisture. Pacific temperate rainforests also tend to have low bulk density, moderate and variable CEC, and be fairly acidic. Low soil $\mathrm{pH}$ is particularly prevalent at higher latitudes where Spodosols are common (Table 4) and Al-saturation is also high. By contrast, base saturation and exchangeable cation concentrations and contents, which are low overall, tend to be higher in the southern portions of the region, where Alfisols are more common. There are numerous pedogenic factors and processes that influence soil properties in NAPC rainforests, and we highlight just a few here.

The supply of soil nutrients, particularly base cations, is influenced by marine inputs and parent materials in NAPC rainforests. Soil parent materials can influence nutrient availability in temperate rainforest soils (e.g. Kranabetter and Banner, 2000; Littke et al., 2011), but differences among surface layers are not necessarily large and can diminish over time (Heilman and Gass, 1974; Kranabetter and Banner, 2000). Studies in coastal OR have found that marine aerosols are the primary source of $\mathrm{Ca}, \mathrm{Mg}$, and $\mathrm{K}$ for many forests, particularly those where local rates of weathering and fresh mineral inputs are constrained (Bockheim and Langley-Turnbaugh, 1997; Compton et al., 2003; Perakis et al., 2006). These investigations also indicate that net cation loss is primarily controlled by the leaching of nitrate and organic anions.

The progression of soils from Inceptisols to Spodosols, and accompanying changes in soil properties, is common throughout the entire NAPC region. This process typically involves redistribution and transformation of $\mathrm{Fe}$ and $\mathrm{Al}$, loss of base cations, and buildup of organic matter. Accumulating organic matter leads to soils with high ECEC, extractable acidity, and $1500 \mathrm{kPa}$ water-holding capacity, and later, declining soil $\mathrm{pH}$ and increasing extractable $\mathrm{Fe}$, especially organic and amorphous forms. Such a progression has been observed in chronosequences in 
southwestern OR (Bockheim et al., 1996), coastal BC (Singleton and Lavkulich, 1987), and southeastern AK (Burt and Alexander, 1996). In the southern portion of the NAPC, this process is often accompanied by desilication, and leads to the development of clay-enriched Spodosols and Ultisols (Bockheim et al., 1996; Langley-Turnbaugh and Bockheim, 1998). In the north, podsolization commonly involves the development of a drainage-restricting hardpan layers, potentially leading to paludification (Klinger, 1996; Ugolini and Mann, 1979).

\subsection{The role of soils in temperate and tropical rainforest ecosystems}

Rainforests generally have high productivity and aboveground biomass, and tall, multilayered canopies. Tropical and temperate rainforests differ in global coverage ( $12 \%$ vs. $2 \%$ ), local tree species richness ( $>50$ vs. $<20$ ), dead organic matter accumulations (low vs. high), and tree lifespans (50-100 vs. 400-1500 yrs; DellaSala et al., 2011; Waring and Franklin, 1979). Likewise, there are similarities and differences in the soils of tropical and temperate rainforests. Soils in both bioregions are moderately deep to deep, have high total $\mathrm{N}$ storage, and tend to be acidic and Al-saturated (Table 6). Whereas the soil temperature and moisture regimes are isomesic and udic in temperate rainforests, they are isohyperthermic (mean annual soil temperature $\geq 22^{\circ} \mathrm{C}$ and difference between mean summer and winter temperatures $<6{ }^{\circ} \mathrm{C}$ ) and perudic in tropical rainforests.

Soils in coastal temperate rainforests tend to be young $(<500 \mathrm{ka})$ and less weathered, while those in tropical rainforests commonly are of early Quaternary to late Tertiary age (>1500 ka) and contain low levels of weatherable minerals, low CEC, and narrow CEC7/clay ratios (Table 6). Whereas the dominant soil-mineral classes are mixed, ferrihydritic, and isotic in soils of temperate rainforests, they are kaolinitic, ferruginous (abundant $\mathrm{Fe}_{2} \mathrm{O}_{3}$ ), or parasesquic (abundant gibbsite and $\mathrm{Fe}_{2} \mathrm{O}_{3}$ ) in soils of tropical rainforests. Soils of both regions tend to be Al-saturated.

A major difference in soils of temperate and tropical rainforest is the storage of SOC. The representative temperate rainforest pedons considered in this study contain a median of $211 \mathrm{Mg} / \mathrm{ha}$, while the tropical rainforest soils from Micronesia contain less, at $162 \mathrm{Mg} / \mathrm{ha}$ (Table 6). Temperate rainforest soils also have substantially higher C:N ratios

\section{Table 6}

Comparison of typical soil characteristics in tropical and temperate rainforests. Quantities represent typical ranges or medians with interquartile ranges in parentheses. For temperate rainforests, characteristics are derived from Table 2 and the 27 representative pedons of North American Pacific coastal rainforests (Table 4, Supplement S1). For tropical rainforests, characteristics are summarized from the soil series in the Perox suborder from Micronesia in the Pacific Basin.

National Cooperative Soil Survey (2013) and Soil Survey Staff (2013c).

\begin{tabular}{lll}
\hline Property & Temperate rainforests & Tropical rainforests \\
\hline Soil depth [cm] & $86-150$ & $>100$ \\
Weatherable minerals [\%] & $>10$ & $<10$ \\
Age [ka BP] & $<500$ & $>1500$ \\
Soil temperature regime & Isomesic, isofrigid & Isohyperthermic \\
Soil moisture regime & Udic, some aquic & Perudic \\
Cation-exchange capacity & $33(17-42)$ & $6(4-10)$ \\
$\quad$ [cmol $(+) / \mathrm{kg}]$ & & \\
Effective CEC [cmol $(+) / \mathrm{kg}]$ & $<2-<15$ & $<1-<10$ \\
CEC7:clay Ratio & $1-6$ & $<1$ \\
Al saturation [\%] & $32-78$ & $44-74$ \\
pH & $4.6-5.3$ & $129(100-236)$ \\
Total base-cation storage & $165(89-315)$ & $162(101-194)$ \\
$\quad$ to $1 \mathrm{~m}[\mathrm{kmol}(+) / \mathrm{ha}]$ & & \\
Soil organic C storage to & $211(116-439)$ & $15,980(14,312-18,172)$ \\
$\quad 1$ m [kg/ha] & & $10.4(7.6-11.3)$ \\
Total N storage to $1 \mathrm{~m}[\mathrm{~kg} / \mathrm{ha}]$ & $15,113(7384-26,013)$ & \\
C:N ratio & $18.1(13.8-21.2)$ & \\
\hline
\end{tabular}

than their tropical counterparts (MD: 18.1 v. 10.4). Base cation pools are just slightly higher in temperate than tropical rainforest soils, which contain medians of 165 and $129 \mathrm{kmol}_{\mathrm{C}}$ /ha, respectively. The profile storage of total $\mathrm{N}$ is high in both bioregions (MD: 15,113 and $15,980 \mathrm{~kg} \mathrm{~N} / \mathrm{ha}$ respectively), though it appears to be more variable in temperate areas, where rainforests can be $\mathrm{N}$-limited or $\mathrm{N}$-saturated (Table 6; Perakis et al., 2006). The abundance of $\mathrm{N}$ in tropical rainforest soils was described as the "nitrogen paradox" by Hedin et al. (2009), in which this buildup of $\mathrm{N}$ does not impact plant physiology and biodiversity. Similar phenomena may be applicable in N-saturated temperate rainforests (Perakis and Sinkhorn, 2011).

The NRCS databases lacked information about plant-available P. Based on the abundance of Spodosols, Andisols, and Histosols, which readily fix $P$, we suspect that $P$ may often be limiting in temperate rainforests. Evidence in support of this has come from studies on Vancouver Island that indicates that forest productivity is co-limited by P and N (Blevins et al., 2006; Kranabetter et al., 2005). Richardson et al. (2004) found that P limitation developed in the older soils of a glacial chronosequence in temperate rainforests in New Zealand. Tropical rainforests are also subject to $P$ deficiencies due to the tight nutrient cycling of that element (Hedin et al., 2009).

These comparisons suggest that soils in temperate rainforests generally are somewhat more fertile than those in tropical rainforests. The storage of nutrients is comparable in some respects, such as large total soil N capacity, but different in others, like SOC and cation-exchange capacity. Of course, forest fertility in these ecosystems is not solely a function of their soils, but also of how nutrients are cycled through their soils.

Both tropical and temperate rainforests utilize biogeochemical pathways that are absent or insignificant in most other ecosystems. A humid climate and tall canopies allow these forests to capture significant quantities of water and nutrients from cloud deposition (Clark et al., 1998; Weathers et al., 2000). Rainforests generally contain abundant epiphytes that both benefit from and enhance cloud-water interception (Coxson and Nadkarni, 1995). Litter and other detritus that collect in rainforest canopies are sufficient to form arboreal Histosols (Enloe et al., 2006). In both types of rainforest, fine roots tend to be concentrated in the topsoil and forest floor, contributing to rapid turnover of organic matter and enabling "direct" nutrient cycling (Stark and Jordan, 1978; Vogt et al., 1983). A substantial proportion of nutrients are immobilized in aboveground biomass in at least some temperate and tropical rainforests (Bormann and Sidle, 1990; Edwards and Grubb, 1982). In temperate rainforests, large accumulations of woody detritus and forest floor biomass can also act as large stores of nutrients, but in tropical areas, rainforests have much higher rates of decomposition and thus smaller dead organic matter pools (Chambers et al., 2000; Vogt et al., 1986).

A major difference in biogeochemical cycling among rainforests is the high rates of nutrient exchange with marine ecosystems in many temperate regions, but few tropical regions. Tropical rainforests commonly occur inland from oceans, whereas nearly all temperate rainforests are on or near coastlines. In the NAPC region, this allows migrating salmon to bring substantial quantities of nutrients, particularly $\mathrm{N}$ and $\mathrm{P}$, from the ocean into forest ecosystems (Gende et al., 2002; Naiman et al., 2002), while marine aerosols can provide significant inputs of K, Ca, and Mg (Bockheim and Langley-Turnbaugh, 1997; Perakis et al., 2006).

Tropical and temperate coastal rainforests have some similar soilforming processes, including base-cation leaching, melanization, and gleization. However, the major difference between these two bioregions is that whereas podsolization is a dominant soil-forming process in temperate rainforests, ferrallitization is of key importance in tropical rainforests. In temperate rainforests the environmental conditions create strongly acid soil solutions that enable the complexation of $\mathrm{Al}$, whereas the lesser acidity of leachates in tropical rainforests enables rapid hydroxylation and the formation of $\mathrm{Al}$ intergrade minerals (Righi et al., 1990). 


\section{Conclusions}

To investigate the characteristics of temperate rainforest soils we delineated the soils in North American Pacific coastal temperate rainforests as a case study, assessed their diversity and properties, and compared them and their role in rainforest ecosystems with their tropical counterparts. We draw the following conclusions:

- Soils of the NAPC temperate rainforest are exceptionally diverse, including 8 orders and 31 suborders, owing to significant heterogeneity in soil-forming factors. There are also a large number of endemic soils in the region, constituting approximately $26 \%$ of described soil series. Within the region, pedodiversity and the proportion of endemic soils is inversely related to latitude.

- Soils of NAPC temperate rainforests are deep, hold abundant moisture, are not subject to deep-freezing, and have abundant weatherable minerals and a moderately high cation-exchange capacity. These soils also tend to be acidic, Al-saturated and enriched in extractable $\mathrm{Fe}$ and $\mathrm{Al}$. Organic $\mathrm{C}$ and total $\mathrm{N}$ contents and $\mathrm{C}: \mathrm{N}$ ratios are high overall, but SOC and $\mathrm{N}$ are also quite variable, with right-skewed, longtailed distributions. Levels of base cations are somewhat low, also with a right-skewed long-tailed distribution.

- Soils in temperate rainforests share some characteristics with tropical rainforest, while differing in others. Both temperate and tropical rainforest soils tend to be deep, acidic, and Al-saturated, and can have high levels of $\mathrm{N}$, and deficiency in P. Soils in temperate rainforests are generally younger and somewhat more fertile, with different and more abundant weatherable minerals. They also have higher $\mathrm{C}$ storage, $\mathrm{C}: \mathrm{N}$ ratios, and cation exchange capacity than tropical rainforest soils.

Supplementary data to this article can be found online at http://dx. doi.org/10.1016/j.geoderma.2014.04.023.

\section{Acknowledgments}

The authors are grateful to the professional soil surveyors and scientists of USDA NRCS, the laboratory technicians, and information technologists that have made the data used in this study generously available to the public.

\section{References}

Alaback, P., 1991. Comparative ecology of temperate rainforests of the Americas along analogous climatic gradients. Rev. Chil. Hist. Nat. 64, 399-412.

Alexander, E.B., Burt, R., 1996. Soil development on moraines of Mendenhall Glacier, southeast Alaska. 1. The moraines and soil morphology. Geoderma 72, 1-17.

Batjes, N.H., 1997. A world dataset of derived soil properties by FAO-UNESCO soil unit for global modelling. Soil Use Manag. 13, 9-16.

BC Ministry of Environment, 2013. BC Soils Information System [WWW Document]. http://www.env.gov.bc.ca/soils/provsoil/index.html (accessed 6.17.13).

Blevins, L.L., Prescott, C.E., Van Niejenhuis, A., 2006. The roles of nitrogen and phosphorus in increasing productivity of western hemlock and western redcedar plantations on northern Vancouver Island. For. Ecol. Manag. 234, 116-122. http://dx.doi.org/10. 1016/j.foreco.2006.06.029.

Bockheim, J.G., 2005. Soil endemism and its relation to soil formation theory. Geoderma 129, 109-124. http://dx.doi.org/10.1016/j.geoderma.2004.12.044.

Bockheim, J.G., Langley-Turnbaugh, S., 1997. Biogeochemical cycling in coniferous ecosystems on different aged marine terraces in coastal Oregon. J. Environ. Qual. 26, 292-301.

Bockheim, J.G., Marshall, J.G., Kelsey, H.M., 1996. Soil-forming processes and rates on uplifted marine terraces in southwestern Oregon, USA. Geoderma 73, 39-62.

Bormann, B.T., Sidle, R.C., 1990. Changes in productivity and distribution of nutrients in a chronosequence at Glacier Bay National Park, Alaska. J. Ecol. 78, 561-578.

Bormann, B.T., Spaltenstein, H., McClellan, M.H., Ugolini, F.C., Cromack Jr., K., Nay, S.M. 1995. Rapid soil development after windthrow disturbance in pristine forests. J. Ecol. 83, 747-757.

Briggs, C.A.D., Busacca, A.J., McDaniel, P.A., 2006. Pedogenic processes and soil-landscape relationships in North Cascades National Park, Washington. Geoderma 137, 192-204. http://dx.doi.org/10.1016/j.geoderma.2006.08.015.
Burt, R., Alexander, E.B., 1996. Soil development on moraines of Mendenhall Glacier, southeast Alaska. 2. Chemical transformations and soil micromorphology. Geoderma $72,19-36$.

Centre for Land and Biological Resources Research, 1996. Soil Landscapes of Canada v.2.2.

Chambers, J.Q., Higuchi, N., Schimel, J.P., Ferreira, L.V., Melack, J.M., 2000. Decomposition and carbon cycling of dead trees in tropical forests of the central Amazon. Oecologia 122, 380-388.

Clark, K.L., Nadkarni, N.M., Schaefer, D., Gholz, H.L., 1998. Atmospheric deposition and net retention of ions by the canopy in a tropical montane forest, Monteverde, Costa Rica. J. Trop. Ecol. 14, 27-45.

Compton, J.E., Church, M.R., Larned, S.T., Hogsett, W.E., 2003. Nitrogen export from forested watersheds in the Oregon Coast range: the role of $\mathrm{N}_{2}$-fixing red alder. Ecosystems 6, 773-785. http://dx.doi.org/10.1007/s10021-002-0207-4.

Coscione, A.R., Moniz, A.C., Pérez, D.V., Ferreira, M.M.C., Camargo, O.A., 2005. Chemical and electrochemical properties of an Oxisol-Ultisol transition in the state of São Paulo, Brazil. Geoderma 126, 375-388. http://dx.doi.org/10.1016/j.geoderma.2004.10.005.

Coxson, D.S., Nadkarni, N.M., 1995. Ecological Roles of Epiphytes in Nutrient Cycles of Forest Ecosystems. For. Canopies Acad. Press, San Diego pp. 495-543.

Crocker, R.L., Dickson, B.A., 1957. Soil development on the recessional moraines of the Herbert and Mendenhall Glaciers, south-eastern Alaska. J. Ecol. 45, 169-185.

D'Amore, D.V., Fellman, J.B., Edwards, R.T., Hood, E., 2010. Controls on dissolved organic matter concentrations in soils and streams from a forested wetland and sloping bog in southeast Alaska. Ecohydrology 3, 249-261. http://dx.doi.org/10.1002/eco. 101

DellaSala, D.A., Alaback, P., Spribille, T., von Wehrden, H., Nauman, R.S., 2011. Just what are temperate and boreal rainforests? Temperate and Boreal Rainforests of the World: Ecology and Conservation. Island Press, pp. 1-41.

Demarchi, D.A., 2011. The British Columbia Ecoregion Classification, Ecosystem Information Section3rd ed. British Columbia Ministry of Environment, Victoria, B.C.

Ecological Stratification Working Group, 1996. A National Ecological Framework for Canada. Agriculture and Agri-Food Canada, Research Branch, Centre for Land and Biological Resources Research, and Environment Canada, State of the Environment Directorate, Ecozone Analysis Branch, Ottawa.

Edmonds, R.L., Chappell, H.N., 1994. Relationships between soil organic matter and forest productivity in western Oregon and Washington. Can. J. For. Res. 24, 1101-1106.

Edwards, P.J., Grubb, P.J., 1982. Studies of mineral cycling in a montane rain forest in New Guinea: IV. Soil characteristics and the division of mineral elements between the vegetation and soil. J. Ecol. 70, 649-666.

Enloe, H.A., Graham, R.C., Sillett, S.C., 2006. Arboreal Histosols in old-growth redwood forest canopies, Northern California. Soil Sci. Soc. Am. J. 70, 408-418.

Gende, S.M., Edwards, R.T., Willson, M.F., Wipfli, M.S., 2002. Pacific salmon in aquatic and terrestrial ecosystems. Bioscience 52, 917. http://dx.doi.org/10.1641/00063568(2002) 052[0917:PSIAAT]2.0.CO;2.

Grand, S., Lavkulich, L.M., 2012. Effects of Forest harvest on soil carbon and related variables in Canadian Spodosols. Soil Sci. Soc. Am. J. 76, 1816. http://dx.doi.org/10. 2136/sssaj2012.0103.

Guo, Y., Gong, P., Amundson, R., 2003. Pedodiversity in the United States of America. Geoderma 117, 99-115. http://dx.doi.org/10.1016/S0016-7061(03)00137-X.

Hartshorn, A.S., Southard, R.J., Bledsoe, C.S., 2003. Structure and function of peatlandforest ecotones in southeastern Alaska. Soil Sci. Soc. Am. J. 67, 1572-1581.

Hedin, L.O., Armesto, J.J., Johnson, A.H., 1995. Patterns of nutrient loss from unpolluted, old-growth temperate forests: evaluation of biogeochemical theory. Ecology 76, 493-509.

Hedin, L.O., Brookshire, E.N.J., Menge, D.N.L., Barron, A.R., 2009. The nitrogen paradox in tropical forest ecosystems. Annu. Rev. Ecol. Evol. Syst. 40, 613-635. http://dx.doi. org/10.1146/annurev.ecolsys.37.091305.110246.

Heilman, P.E., Gass, C.R., 1974. Parent materials and chemical properties of mineral soils in southeast Alaska. Soil Sci. 117, 21-27.

Heuscher, S.A., Brandt, C.C., Jardine, P.M., 2005. Using soil physical and chemical properties to estimate bulk density. Soil Sci. Soc. Am. J. 69, 51-56.

Homann, P.S., Remillard, S.M., Harmon, M.E., Bormann, B.T., 2004. Carbon storage in coarse and fine fractions of Pacific Northwest old-growth forest soils. Soil Sci. Soc. Am. J. 68, 2023-2030.

Homann, PS, Harmon, M, Remillard, S, Smithwick, EA.H, 2005. What the soil reveals: potential total ecosystem C stores of the Pacific Northwest region, USA. For. Ecol. Manag. 220, 270-283. http://dx.doi.org/10.1016/j.foreco.2005.08.035.

Homann, P.S., Kapchinske, J.S., Boyce, A., 2007. Relations of mineral-soil C and N to climate and texture: regional differences within the conterminous USA. Biogeochemistry 85, 303-316. http://dx.doi.org/10.1007/s10533-007-9139-6.

Hudiburg, T., Law, B., Turner, D.P., Campbell, J., Donato, D., Duane, M., 2009. Carbon dynamics of Oregon and Northern California forests and potential land-based carbon storage. Ecol. Appl. 19, 163-180.

Huygens, D., Boeckx, P., Templer, P., Paulino, L., Van Cleemput, O., Oyarzún, C., Müller, C., Godoy, R., 2008. Mechanisms for retention of bioavailable nitrogen in volcanic rainforest soils. Nat. Geosci. 1, 543-548. http://dx.doi.org/10.1038/ngeo252.

Jungen, J.R., Lewis, T., 1978. The Coast Mountains and Islands. The Soil Landscapes of British Columbia. BC Ministry of the Environment, Resource Analysis Branch, British Columbia.

Keith, H., Mackey, B.G., Lindenmayer, D.B., 2009. Re-evaluation of forest biomass carbon stocks and lessons from the world's most carbon-dense forests. Proc. Natl. Acad. Sci. $106,11635-11640$.

Kellogg, E.L., 1992. Coastal temperate rain forests: ecological characteristics. Status and Distribution Worldwide (No. Occasional Paper Series No. 1)Ecotrust Publications, Portland OR.

Kimmins, J.P., 1996. Importance of soil and role of ecosystem disturbance for sustained productivity of cool temperate and boreal forests. Soil Sci. Soc. Am. J. 60, 1643-1654. 
Klinger, L.F., 1996. Coupling of soils and vegetation in peatland succession. Arct. Alp. Res. 380-387.

Kramer, M.G., Sollins, P., Sletten, R.S., 2004. Soil carbon dynamics across a windthrow disturbance sequence in southeast Alaska. Ecology 85, 2230-2244.

Kranabetter, J.M., Banner, A., 2000. Selected biological and chemical properties of forest floors across bedrock types on the north coast of British Columbia. Can. J. For. Res. 30, 971-981.

Kranabetter, J.M., Banner, A., de Groot, A., 2005. An assessment of phosphorus limitations to soil nitrogen availability across forest ecosystems of north coastal British Columbia. Can. J. For. Res. 35, 530-540. http://dx.doi.org/10.1139/x04-192.

Langley-Turnbaugh, S.J., Bockheim, J.G., 1998. Mass balance of soil evolution on late Quaternary marine terraces in coastal Oregon. Geoderma 84, 265-288.

Lawford, R.G., Alaback, P., Fuentes, E., 1995. High-latitude Rainforests and Associated Ecosystems of the West Coast of the Americas: Climate, Hydrology. Springer, Ecology and Conservation.

Littke, K.M., Harrison, R.B., Briggs, D.G., Grider, A.R., 2011. Understanding soil nutrients and characteristics in the Pacific Northwest through parent material origin and soil nutrient regimes. Can. J. For. Res. 41, 2001-2008. http://dx.doi.org/10.1139/x11-115.

Mann, D.H., Hamilton, T.D., 1995. Late Pleistocene and Holocene paleoenvironments of the North Pacific coast. Quat. Sci. Rev. 14, 449-471.

Menge, D.N.L., Troy Baisden, W., Richardson, S.J., Peltzer, D.A., Barbour, M.M., 2011. Declining foliar and litter $\delta^{15} \mathrm{~N}$ diverge from soil, epiphyte and input $\delta^{15} \mathrm{~N}$ along a 120000 yr temperate rainforest chronosequence. New Phytol. 190, 941-952. http://dx.doi.org/10.1111/j.1469-8137.2010.03640.x.

Merritts, D.J., Chadwick, O.A., Hendricks, D.M., 1991. Rates and processes of soil evolution on uplifted marine terraces, northern California. Geoderma 51, 241-275.

Minasny, B., McBratney, A.B., Hartemink, A.E., 2010. Global pedodiversity, taxonomic distance, and the World Reference Base. Geoderma 155, 132-139. http://dx.doi.org/10. 1016/j.geoderma.2009.04.024

Morford, S.L., Houlton, B.Z., Dahlgren, R.A., 2011. Increased forest ecosystem carbon and nitrogen storage from nitrogen rich bedrock. Nature 477, 78-81. http://dx.doi.org/ 10.1038/nature10415.

Naiman, R.J., Bilby, R.E., Schindler, D.E., Helfield, J.M., 2002. Pacific salmon, nutrients, and the dynamics of freshwater and riparian ecosystems. Ecosystems 5, 399-417. http:// dx.doi.org/10.1007/s10021-001-0083-3.

National Cooperative Soil Survey, 2013. National Cooperative Soil Characterization Database [WWW Document]. U. S. Dep. Agric. Nat. Resour. Conserv. Serv URL http://ncsslabdatamart.sc.egov.usda.gov/ (accessed 9.20.13).

Natural Resource Conservation Service, 2006. Land resource regions and major land resource areas of the United States, the Caribbean, and the Pacific Basin. United States Department of Agriculture Handbook 296.

Padmanabhan, E., Eswaran, H., Mermut, A.R., 2012. Classifying soils at the ultimate stage of weathering in the tropics. J. Plant Nutr. Soil Sci. 175, 86-93. http://dx.doi.org/10. 1002/jpln.201000348.

Perakis, S.S., Sinkhorn, E.R., 2011. Biogeochemistry of a temperate forest nitrogen gradient. Ecology 92, 1481-1491.

Perakis, S.S., Maguire, D.A., Bullen, T.D., Cromack, K., Waring, R.H., Boyle, J.R., 2006. Coupled nitrogen and calcium cycles in forests of the Oregon Coast range. Ecosystems 9, 63-74. http://dx.doi.org/10.1007/s10021-004-0039-5.

Perakis, S.S., Sinkhorn, E.R., Compton, J.E., 2011. $\delta^{15} \mathrm{~N}$ constraints on long-term nitrogen balances in temperate forests. Oecologia 167, 793-807. http://dx.doi.org/10.1007/ s00442-011-2016-y.

Post, W.M., Emanuel, W.R., Zinke, P.J., Stangenberger, A.G., 1982. Soil Carbon Pools and World Life Zones.

Post, W.M., Pastor, J., Zinke, P.J., Stangenberger, A.G., 1985. Global patterns of soil nitrogen storage. Nature 317, 613-616.

Remillard, S.M., 1999. Soil carbon and nitrogen in old-growth forests in western Oregon and Washington. (M.S. Thesis) (Corvallis, OR).

Richardson, S.J., Peltzer, D.A., Allen, R.B., McGlone, M.S., Parfitt, R.L., 2004. Rapid development of phosphorus limitation in temperate rainforest along the Franz Josef soil chronosequence. Oecologia 139, 267-276. http://dx.doi.org/10.1007/s00442-0041501-y.
Righi, D., Bravard, S., Chavel, A., Ranger, J., Robert, M., 1990. In-situ study of soil processes in oxisol-spodosol sequence of Amazonia (Brazil). Soil Sci. 150, 438-445.

Schuur, E.A., Chadwick, O.A., Matson, P.A., 2001. Carbon cycling and soil carbon storage in mesic to wet Hawaiian montane forests. Ecology 82, 3182-3196.

Singleton, G.A., Lavkulich, L.M., 1987. A soil chronosequence on beach sands, Vancouver Island, British Columbia. Can. J. Soil Sci. 67, 795-810.

Sinkhorn, E.R., 2007. Non-linear nitrogen dynamics and calcium depletion along a temperate forest soil nitrogen gradient. (M.S. Thesis) Oregon State University, Corvallis, OR.

Smithwick, E.A.H., Harmon, M.E., Remillard, S.M., Acker, S.A., Franklin, J.F., 2002. Potential upper bounds of carbon stores in forests of the Pacific Northwest. Ecol. Appl. 12, 1303-1317.

Soil Classification Working Group, 1998. The Canadian System of Soil Classification, 3rd ed. National Research Council of Canada, Ottawa, ON.

Soil Survey Staff, 2012. The Gridded Soil Survey Geographic (SSURGO) Database for the United States of America and the Territories, Commonwealths, and Island Nations Served by the USDA-NRCS [WWW Document]. U. S. Dep. Agric. Nat. Resour. Conserv. Serv (URL http://datagateway.nrcs.usda.gov/ (accessed 10.15.12)).

Soil Survey Staff, 2013a. U.S. General Soil Map (STATSGO2) [WWW Document]. U. S. Dep. Agric. Nat. Resour. Conserv. Serv (URL http://soils.usda.gov/survey/geography/ ssurgo/description_statsgo2.html (accessed 9.20.13)).

Soil Survey Staff, 2013b. Soil Series Classification Database [WWW Document]. U. S. Dep. Agric. Nat. Resour. Conserv. Serv (URL http://soils.usda.gov/technical/classification/ scfile/index.html (accessed 9.20.13)).

Soil Survey Staff, 2013c. Official Soil Series Descriptions [WWW Document]. U. S. Dep. Agric. Nat. Resour. Conserv. Serv (URL http://soils.usda.gov/technical/classification/ osd/index.html (accessed 9.20.13)).

Stark, N.M., Jordan, C.F., 1978. Nutrient retention by the root mat of an Amazonian rain forest. Ecology 59, 434-437.

Sun, O.J., Campbell, J., Law, B.E., Wolf, V., 2004. Dynamics of carbon stocks in soils and detritus across chronosequences of different forest types in the Pacific Northwest, USA. Global Change Biol. 10, 1470-1481. http://dx.doi.org/10.1111/j.1365-2486.2004. 00829.x.

Turunen, C., Turunen, J., 2003. Development history and carbon accumulation of a slope bog in oceanic British Columbia, Canada. The Holocene 13, 225-238. http://dx.doi org/10.1191/0959683603hl609rp.

Ugolini, F.C., 1968. Soil development and alder invasion in a recently deglaciated area of Glacier Bay, Alaska. In: Trappe, J.M., Franklin, J.F., Tarrant, R.F., Hansen, G.M. (Eds.) Biology of Red Alder. USDA Forest Service, Pacific Northwest Forest and Range Experimental Station, Portland, OR, pp. 115-148.

Ugolini, F.C., Mann, D.H., 1979. Biopedological origin of peatlands in South East Alaska. Nature 281, 366-368.

Vogt, K.A., Grier, C.C., Meier, C.E., Keyes, M.R., 1983. Organic matter and nutrient dynamics in forest floors of young and mature Abies amabilis stands in western Washington, as affected by fine-root input. Ecol. Monogr. 53, 139-157.

Vogt, K.A., Grier, C.C., Vogt, D.J., 1986. Production, turnover, and nutrient dynamics of above- and belowground detritus of world forests. In: MacFayden, A., Ford, E.D. (Eds.), Advances in Ecological Research 15, Advances in Ecological Research. Academic Press, pp. 303-377.

Waring, R.H., Franklin, J.F., 1979. Evergreen coniferous forests of the Pacific Northwest. Science 204, 1380-1386.

Weathers, K.C., Lovett, G.M., Likens, G.E., Caraco, N.F.M., 2000. Cloudwater inputs of nitrogen to forest ecosystems in southern Chile: forms, fluxes, and sources. Ecosystems 3 , 590-595. http://dx.doi.org/10.1007/s100210000051.

Wiken, E., Jiménez Nava, F., Griffith, G., 2011. North American Terrestrial Ecoregions-Leve III. Commission for Environmental Cooperation, Montreal, Canada.

Zinke, P.J., Stangenberger, A.G., Post, W.M., Emanuel, W.R., Olson, J.S., 1998. Global Organic Soil Carbon and Nitrogen Data Set [WWW Document]. Oak Ridge Natl. Lab. Distrib. Act. Arch. Cent (URL http://daac.ornl.gov/SOILS/guides/zinke_soil.html (accessed 2. 13.14)). 